\title{
Half-Sandwich Complexes of Iridium and Ruthenium Containing Cysteine-Derived Ligands $\dagger$
}

María Carmona, ${ }^{a}$ Ricardo Rodríguez, ${ }^{\text {a, }}$ Fernando J. Lahoz, ${ }^{\text {a }}$ Pilar García-Orduña, ${ }^{a}$ Carlos Cativiela, ${ }^{b}$ José A. López ${ }^{\mathrm{a}}$ and Daniel Carmona,

Received ......

DOI:

The dimers $\left[\left\{\left(\eta^{\mathrm{n}} \text {-ring }\right) \mathrm{MCl}\right\}_{2}(\mu-\mathrm{Cl})_{2}\right]\left(\left(\eta^{\mathrm{n}}\right.\right.$-ring $\left.) \mathrm{M}=\left(\eta^{5}-\mathrm{C}_{5} \mathrm{Me}_{5}\right) \mathrm{Ir},\left(\eta^{6}-p-\mathrm{MeC}_{6} \mathrm{H}_{4} i \mathrm{Pr}\right) \mathrm{Ru}\right)$ react with the modified cysteines $S$-benzyl- $L$-cysteine (HL1) or $S$-benzyl- $\alpha$-methyl- $L$ cysteine (HL2) rendering cationic complexes of formula $\left[\left(\eta^{\mathrm{n}}-\mathrm{ring}\right) \mathrm{MCl}\left(\kappa^{2} N, S-\mathbf{H L}\right)\right] \mathrm{Cl}$ $(\mathbf{1}, \mathbf{2})$ in good yield. Addition of $\mathrm{NaHCO}_{3}$ to complexes $\mathbf{1}$ and $\mathbf{2}$ gave equilibrium mixtures of neutral $\left[\left(\eta^{\mathrm{n}}\right.\right.$-ring $\left.) \mathrm{MCl}\left(\kappa^{2} N, O-\mathbf{L}\right)\right](3,4)$ and cationic $\left[\left(\eta^{\mathrm{n}}-\operatorname{ring}\right) \mathrm{M}\left(\kappa^{3} N, O, S\right.\right.$ $\mathbf{L})] \mathrm{Cl}(\mathbf{6 C l}, \mathbf{7 C l})$ complexes. Similar mixtures were obtained in one-pot reaction by successive addition of the modified cysteine and $\mathrm{NaHCO}_{3}$ to the above formulated dimers. Addition of the $N$-Boc substituted cysteine derivative $S$-benzyl- $N$-Boc- $L$ cysteine (HL3) and $\mathrm{NaHCO}_{3}$ to the dimers $\left[\left\{\left(\eta^{\mathrm{n}} \text {-ring }\right) \mathrm{MCl}\right\}_{2}(\mu-\mathrm{Cl})_{2}\right]$ affords the neutral compounds $\quad\left[\left(\eta^{\mathrm{n}}\right.\right.$-ring $\left.) \mathrm{MCl}\left(\kappa^{2} O, S-\mathbf{L} 3\right)\right] \quad\left(\left(\eta^{\mathrm{n}}\right.\right.$-ring $) \mathrm{M}=\left(\eta^{5}-\mathrm{C}_{5} \mathrm{Me}_{5}\right) \mathrm{Ir} \quad(\mathbf{5 a}), \quad\left(\eta^{6}-p\right.$ $\left.\left.\mathrm{MeC}_{6} \mathrm{H}_{4} i \mathrm{Pr}\right) \mathrm{Ru}(\mathbf{5 b})\right)$. Complexes of formula [( $\eta^{\mathrm{n}}$-ring $\left.) \mathrm{MCl}\left(\kappa^{3} N, O, S-\mathbf{L}\right)\right]\left[\mathrm{SbF}_{6}\right](\mathbf{6 S b}-$ 8Sb), in which the cysteine derivative acts as tridentate chelate ligand, can be prepared by adding one equivalent of $\mathrm{AgSbF}_{6}$ to solutions of compounds 5 or to mixtures of complexes $\mathbf{3 / 6 C l}$ and $\mathbf{4 / 7 C l}$. The amide proton of compounds $\mathbf{8 a S b}$ and $\mathbf{8 b S b}$ can be removed by addition of $\mathrm{NaHCO}_{3}$ affording the neutral complexes $\left[\left(\eta^{\mathrm{n}}\right.\right.$-ring) $\mathrm{M}\left(\kappa^{3} N, O, S\right.$ L3-H)] (( $\eta^{\mathrm{n}}$-ring)M $\left.=\left(\eta^{5}-\mathrm{C}_{5} \mathrm{Me}_{5}\right) \operatorname{Ir}(\mathbf{9 a}),\left(\eta^{6}-p-\mathrm{MeC}_{6} \mathrm{H}_{4} i \mathrm{Pr}\right) \mathrm{Ru}(\mathbf{9 b})\right)$. Complexes 9a and 9b can also be prepared by reacting the dimers $\left[\left\{\left(\eta^{\mathrm{n}} \text {-ring }\right) \mathrm{MCl}\right\}_{2}(\mu-\mathrm{Cl})_{2}\right]$ with $\mathbf{H L} \mathbf{3}$ and two equivalents of $\mathrm{NaHCO}_{3}$. The absolute configuration of the complexes has been established by spectroscopic and diffractometric means including the crystal structure determination of $\quad\left(R_{\mathrm{Ir}}, R_{\mathrm{C}}, R_{\mathrm{S}}\right)-\left[\left(\eta^{5}-\mathrm{C}_{5} \mathrm{Me}_{5}\right) \operatorname{Ir}\left(\kappa^{3} N, O, S-\mathbf{L} \mathbf{1}\right)\right]\left[\mathrm{SbF}_{6}\right] \quad$ (6aSb). The 
thermodynamic parameters associated to the epimerization at sulphur that undergoes the iridium compound $\left[\left(\eta^{5}-\mathrm{C}_{5} \mathrm{Me}_{5}\right) \operatorname{Ir}\left(\kappa^{3} N, O, S-\mathbf{L} \mathbf{3}_{-\mathbf{H}}\right)\right]$ (9a) have been determined through variable temperature ${ }^{1} \mathrm{H}$ NMR studies.

\footnotetext{
${ }^{a}$ Instituto de Síntesis Química y Catálisis Homogénea (ISQCH), CSIC - Universidad de Zaragoza, Departamento de Química Inorgánica, Pedro Cerbuna 12, 50009 Zaragoza, Spain, E-mail: dcarmona@unizar.es,riromar@unizar.es

${ }^{b}$ Instituto de Síntesis Química y Catálisis Homogénea (ISQCH), CSIC - Universidad de Zaragoza, Departamento de Química Orgánica, Pedro Cerbuna 12, 50009 Zaragoza, Spain

† Electronic supplementary information (ESI) available: Intermolecular interactions in $\mathbf{6 a S b}$. Full details of the structural analysis of the complex 6aSb (CIF format): CCDC 1490041. For ESI and crystallographic data in CIF or other electronic format see DOI:
} 


\section{Introduction}

The coordination chemistry of $\alpha$-amino acids towards transition-metal ions has been extensively studied ${ }^{1}$ mostly due to the extremely important role that the resulting compounds play in a wide variety of biological processes. ${ }^{2}$ This biological activity is often closely related to the nature of the metallic species. Changes in the nuclearity or structure of the complexes can strongly modify their biological properties but also small variations in the ligands or in their coordination modes may be enough to dramatically alter reactivities. ${ }^{3}$

Sulphur-containing $\alpha$-amino acids play a key role in living systems. ${ }^{4}$ For example, cysteine, methionine and glutathione appear to be crucial in the biological chemistry of platinum anticancer agents $^{5}$ and silver (I) acetylmethioninates showed effective antimicrobial activities against two Gram-negative bacteria and two yeasts. ${ }^{6}$

Cysteine exhibits a wide variety of coordination modes to transition metals including monodentate, bidentate or tridentate chelate as well as bidentate chelate and bridge at the same time, among others. Although the biological activity of the derived complexes depends on both the product distribution and rates of interconversion, the factors that govern these features are far for being understood. ${ }^{7}$

On the other hand, cyclopentadienyl-iridium(III) and arene-ruthenium(II) complexes, containing a wide range of ligands, have shown important biological activity as potent anticancer agents both in vivo and in vitro. ${ }^{8,9}$ For example, halfsandwich iridium(III) complexes containing 2-phenylpyridine ligands bind strongly nucleobase 9EtG indicating that DNA could be a target for these complexes ${ }^{8 \mathrm{~b}}$ and halfsandwich ruthenium (II) complexes containing diaminohexopyranosides as ligands have shown in vitro antiproliferative activity against different cancer cells. ${ }^{9 e}$ 
In the present paper, we study the coordination chemistry of the cysteine-derived ligands $S$-benzyl- $L$-cysteine (HL1), $S$-benzyl- $\alpha$-methyl- $L$-cysteine (HL2) and $S$-benzyl$N$-Boc- $L$-cysteine (HL3) towards $\left(\eta^{5}-\mathrm{C}_{5} \mathrm{Me}_{5}\right) \mathrm{Ir}$ and $\left(\eta^{6}-p-\mathrm{MeC}_{6} \mathrm{H}_{4} i \mathrm{Pr}\right) \mathrm{Ru}$ moieties. Special attention is paid to the different coordination modes that the modified cysteines display and to the stereochemistry of the resulting complexes. 


\section{Results and discussion}

\section{Synthesis of the metallic compounds.}

The synthetic routes developed for the preparation of the new compounds are depicted in Scheme 1. The dimers $\left[\left\{\left(\eta^{\mathrm{n}} \text {-ring }\right) \mathrm{MCl}\right\}_{2}(\mu-\mathrm{Cl})_{2}\right]\left(\left(\eta^{\mathrm{n}}-\mathrm{ring}\right) \mathrm{M}=\left(\eta^{5}-\mathrm{C}_{5} \mathrm{Me}_{5}\right) \mathrm{Ir}^{10}{ }^{10}\left(\eta^{6}-p\right.\right.$ $\left.\left.\mathrm{MeC}_{6} \mathrm{H}_{4} \mathrm{Pr}\right) \mathrm{Ru}\right)^{11}$ react with the modified cysteines $S$-benzyl- $L$-cysteine (HL1) or $S$ benzyl- $\alpha$-methyl-L-cysteine (HL2) (Chart 1) rendering cationic complexes of formula $\left[\left(\eta^{\mathrm{n}}\right.\right.$-ring) $\left.\mathrm{MCl}\left(\kappa^{2} N, S-\mathbf{H L}\right)\right] \mathrm{Cl}(\mathbf{1}, \mathbf{2})$ in good yield. However, the addition of the $N$-Boc substituted cysteine derivative S-benzyl- $N$-Boc- $L$-cysteine (HL3) to solutions of the dimers gave intractable mixtures of unidentified species together with unreacted starting materials.

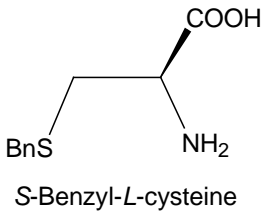

HL1

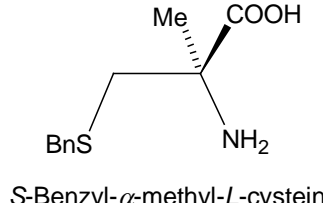

HL2

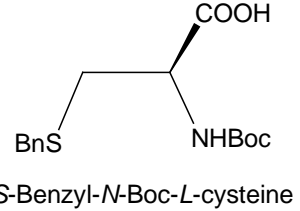

HL3

Chart 1. Modified cysteines

Addition of $\mathrm{NaHCO}_{3}$ to complexes 1 and 2 gave equilibrium mixtures of neutral $\left[\left(\eta^{\mathrm{n}}\right.\right.$-ring) $\left.\mathrm{MCl}\left(\kappa^{2} N, O-\mathbf{L}\right)\right](\mathbf{3}, \mathbf{4})$ and cationic $\left[\left(\eta^{\mathrm{n}}\right.\right.$-ring $\left.) \mathrm{M}\left(\kappa^{3} N, O, S-\mathbf{L}\right)\right] \mathrm{Cl}(\mathbf{6 C l}, \mathbf{7 C l})$ complexes. Similar mixtures were obtained in one-pot reaction by successive addition of the corresponding cysteine-derived ligand and $\mathrm{NaHCO}_{3}$ to the above formulated dimers.

The $N$-Boc protected ligand HL3 also behaves differently in basic medium. Thus, when $\mathbf{H L 3}$ and $\mathrm{NaHCO}_{3}$ were added to the dimers $\left[\left\{\left(\eta^{\mathrm{n}} \text {-ring }\right) \mathrm{MCl}\right\}_{2}(\mu-\mathrm{Cl})_{2}\right]$, the neutral compounds $\left[\left(\eta^{\mathrm{n}}\right.\right.$-ring $\left.) \mathrm{MCl}\left(\kappa^{2} O, S-\mathbf{L} 3\right)\right] \quad\left(\left(\eta^{\mathrm{n}}\right.\right.$-ring $) \mathrm{M}=\left(\eta^{5}-\mathrm{C}_{5} \mathrm{Me}_{5}\right) \operatorname{Ir} \quad(\mathbf{5 a}), \quad\left(\eta^{6}-p\right.$ $\left.\mathrm{MeC}_{6} \mathrm{H}_{4} i \mathrm{Pr}\right) \mathrm{Ru}(\mathbf{5 b})$ ), in which the amino carboxylate shows a $\kappa^{2} O, S$ coordination 
mode, were isolated. However, nitrogen coordination can be forced by removing the chloride with subsequent generation of a vacant site. Thus, addition of one equivalent of $\mathrm{AgSbF}_{6}$ to complexes 5 gave rise to the cationic complexes $\left[\left(\eta^{\mathrm{n}}\right.\right.$-ring $) \mathrm{M}\left(\kappa^{3} N, O, S\right.$ L3) $]\left[\mathrm{SbF}_{6}\right]\left(\left(\eta^{\mathrm{n}}\right.\right.$-ring) $\left.\mathrm{M}=\left(\eta^{5}-\mathrm{C}_{5} \mathrm{Me}_{5}\right) \operatorname{Ir}(\mathbf{8 a S b}),\left(\eta^{6}-p-\mathrm{MeC}_{6} \mathrm{H}_{4} i \mathrm{Pr}\right) \mathrm{Ru}(\mathbf{8 b S b})\right)$ in which, along with the sulphur and the oxygen, the nitrogen atom is also coordinated to the metal. The $\mathbf{L} \mathbf{1}$ and $\mathbf{L} 2$ containing cationic analogues $\left[\left(\eta^{\mathrm{n}}\right.\right.$-ring $\left.) \mathrm{M}\left(\kappa^{3} N, O, S-\mathbf{L}\right)\right]\left[\mathrm{SbF}_{6}\right]$ $\left(\left(\eta^{\mathrm{n}}\right.\right.$-ring) $\mathrm{M}=\left(\eta^{5}-\mathrm{C}_{5} \mathrm{Me}_{5}\right) \mathrm{Ir}, \mathbf{L}=\mathbf{L 1}(\mathbf{6 a S b}), \mathbf{L 2}(\mathbf{7 a S b}) ; \eta^{\mathrm{n}}$-ring $=\left(\eta^{6}-p-\mathrm{MeC}_{6} \mathrm{H}_{4} i \mathrm{Pr}\right) \mathrm{Ru}$ $\mathbf{L}=\mathbf{L 1}(\mathbf{6 b S b}), \mathbf{L} 2$ (7bSb)) were isolated by adding one equivalent of $\mathrm{AgSbF}_{6}$ to mixtures of $\mathbf{3}$ and $\mathbf{6 C l}$ or $\mathbf{4}$ and $\mathbf{7 C l}$.

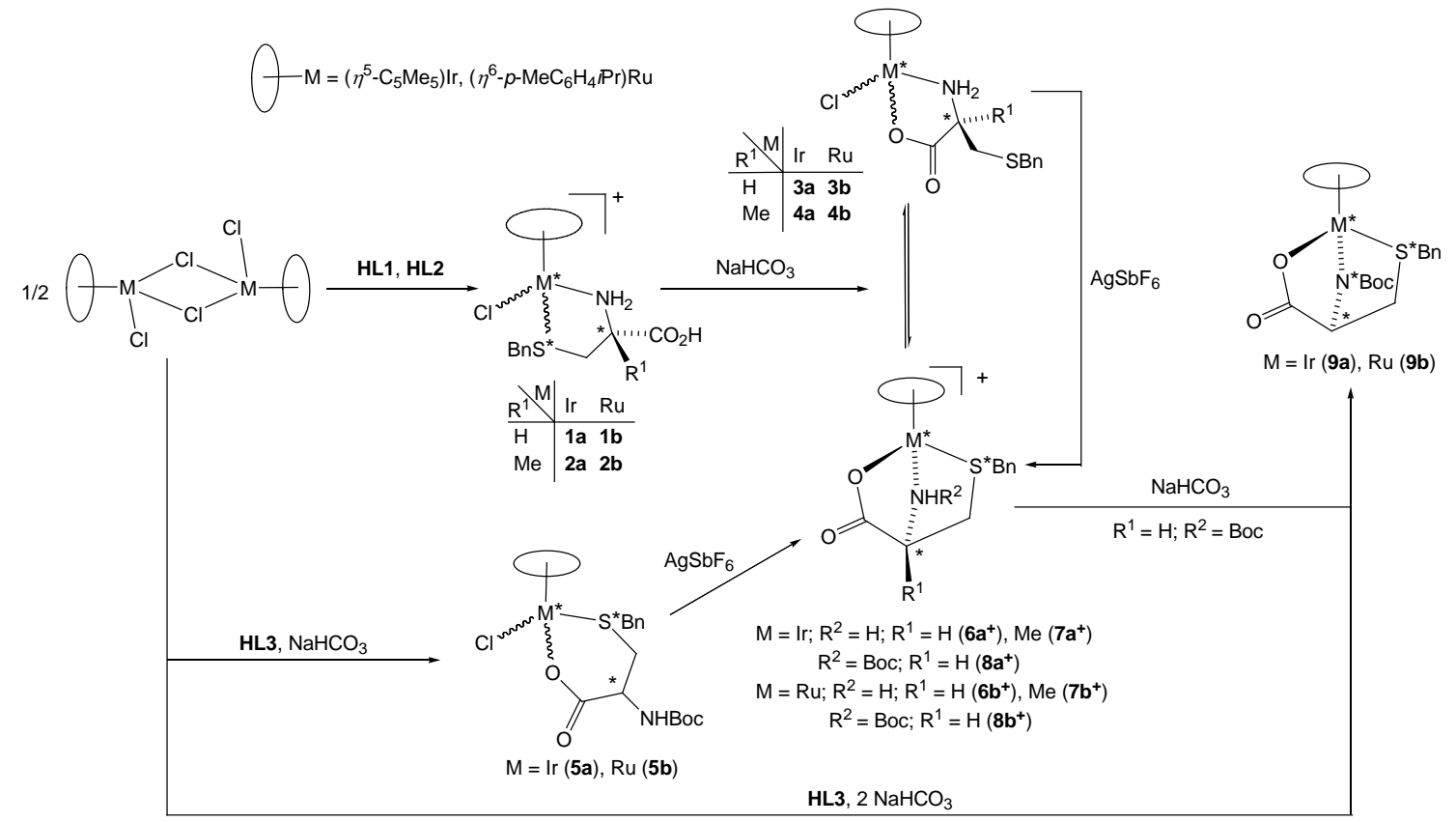

Scheme 1. Preparative routes for complexes 1-9

Finally, the amide proton of compounds $\mathbf{8 a S b}$ and $\mathbf{8 b S b}$ can be removed by addition of $\mathrm{NaHCO}_{3}$ affording the neutral complexes 9a and $\mathbf{9 b}$, respectively. Alternatively, complexes $\mathbf{9}$ can also be prepared by reacting the dimers $\left[\left\{\left(\eta^{\mathrm{n}}-\right.\right.\right.$ ring) $\left.\mathrm{MCl}\}_{2}(\mu-\mathrm{Cl})_{2}\right]$ with $\mathbf{H L 3}$ and two equivalents of $\mathrm{NaHCO}_{3}$.

All these preparative routes are essentially similar to those recently reported for the $\left(\eta^{5}-\mathrm{C}_{5} \mathrm{Me}_{5}\right) \mathrm{Rh}$ analogues. ${ }^{12}$ 
Molecular structure of the complex $\left(R_{\mathrm{Ir}}, R_{\mathrm{C}}, R_{\mathrm{S}}\right)-\left[\left(\eta^{5}-\mathrm{C}_{5} \mathrm{Me}_{5}\right) \operatorname{Ir}\left(\kappa^{3} N, O, S-\mathrm{L} 1\right)\right]\left[\mathrm{SbF}_{6}\right]$ (6aSb).

Single crystals of the complex were grown by slow diffusion of diethyl ether into dry methanolic solutions of the compound and the solid state molecular structure was determined by X-ray diffraction. A molecular representation of the cation is depicted in Figure 1 and selected geometrical parameters are listed in Table 1. The structural features found in $\mathbf{6} \mathbf{a S b}$ are similar to those recently reported for the rhodium analogue $\left[\left(\eta^{5}-\mathrm{C}_{5} \mathrm{Me}_{5}\right) \mathrm{Rh}\left(\kappa^{3} N, O, S-\mathbf{L 1}\right)\right]\left[\mathrm{SbF}_{6}\right] .{ }^{12}$ Complex $\mathbf{6 a S b}$ exhibits the common "threelegged piano-stool” geometry, with three fac positions occupied by an $\eta^{5}-\mathrm{C}_{5} \mathrm{Me}_{5}$ group and the three remaining coordination sites held by the $S$-benzyl- $L$-cysteine which adopts a $\kappa^{3} N, O, S$ coordination mode. According to the ligand priority sequence, ${ }^{13}$ the absolute configuration is $R_{\mathrm{Ir}}, R_{\mathrm{C}}, S_{\mathrm{S}}$.

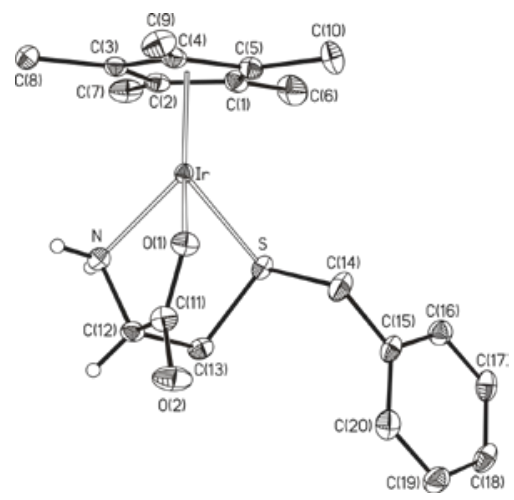

Figure 1. Molecular representation of the cation of $\mathbf{6 a S b}$

Table 1. Selected bond distances $(\AA)$ and angles $\left(^{\circ}\right)$ for $\mathbf{6 a S b}$

\begin{tabular}{|c|c|c|c|}
\hline Ir-S & $2.3646(9)$ & S-Ir-O(1) & 85.32(7) \\
\hline Ir-N & $2.137(3)$ & S-Ir-Ct ${ }^{a}$ & $131.03(4)$ \\
\hline $\operatorname{Ir}-\mathrm{O}(1)$ & $2.114(2)$ & $\mathrm{N}-\mathrm{Ir}-\mathrm{O}(1)$ & $75.28(11)$ \\
\hline $\mathrm{Ir}-\mathrm{Ct}^{a}$ & $1.7812(1)$ & $\mathrm{N}-\mathrm{Ir}-\mathrm{Ct} \mathrm{t}^{\mathrm{a}}$ & 134.91(8) \\
\hline S-Ir-N & $81.40(8)$ & $\mathrm{O}(1)-\mathrm{Ir}-\mathrm{Ct}^{a}$ & $128.79(6)$ \\
\hline
\end{tabular}

${ }^{a} \mathrm{Ct}$ represents the centroid of the $\eta^{5}-\mathrm{C}_{5} \mathrm{Me}_{5}$ ring 
The tridentate coordination of $S$-benzyl- $L$-cysteine leads to the formation of two five-membered, Ir-O-C-C-N and Ir-S-C-C-N, and one six-membered Ir-S-C-C-C-O metallacycles. Ring puckering parameters ( $q=0.558(3), \Phi=155.2(3)^{\circ} ; q=0.632(3), \varphi$ $=-41.1(3)^{\circ} ; q=1.240(2), \varphi=-170.0(1)^{\circ} ; \theta=100.7(1)^{\circ} ;$ respectively $^{14}$ are characteristic of ${ }^{5} \mathrm{E} / \mathrm{T}_{1}, \mathrm{E}_{5}$ and $\mathrm{B}_{4,1}$ conformations. The adopted conformations in the metallacycles minimize the steric impediments between the bulkiest fragments, with the $\mathrm{C}_{5} \mathrm{Me}_{5}$ and benzyl groups occupying pseudoequatorial and pseudoaxial positions, respectively, in the six-membered ring.

Comparison of the structure of $\mathbf{6 a S b}$ with that of the isolated $S$-benzyl- $L$-cysteine, whose crystal structure exhibits two independent molecules, ${ }^{15}$ revealed the lengthening of S-C(13) (6aSb: 1.832(4) Å, HL1: $1.810(3)$ and 1.805(4) $\AA$ ) and $\mathrm{O}(1)-\mathrm{C}(11)$ bonds (1.292(4) Å, HL1: 1.268(4) and 1.258(4) Å), due to the coordination of sulphur and oxygen atom to the metal. However, the $\mathrm{N}-\mathrm{C}(12)$ bond is less affected (6aSb: $1.478(4)$ Å, HL1: $1.486(4)$ and 1.496(4) $\AA$ ).

Protons of the $\mathrm{NH}_{2}$ fragment of the cysteine derivative are involved in strong $\mathrm{N}$ $\mathrm{H} \cdots \mathrm{O}$ hydrogen bonds and weak $\mathrm{N}-\mathrm{H} \cdots \pi$ interactions with carboxylate and benzyl groups of neighbouring molecules, stabilizing the solid state structure (See ESI†).

\section{Characterization of the metallic compounds}

The new complexes were characterized by analytical and spectroscopic means (see Experimental section). Assignment of the NMR signals was verified by two dimensional homonuclear and heteronuclear correlations. The IR spectra showed strong $v(\mathrm{C}=\mathrm{O})$ absorptions in the $1610-1730 \mathrm{~cm}^{-1}$ range (carboxylate) and around $1760 \mathrm{~cm}^{-1}$ (Boc). ${ }^{16}$ The $\mathrm{SbF}_{6}$ derivatives present a strong band around $650 \mathrm{~cm}^{-1}$ attributed to this 
anion. The ${ }^{1} \mathrm{H}$ NMR data are consistent with the presence of the $\mathrm{C}_{5} \mathrm{Me}_{5}$ and cysteinederived ligands in a 1:1 molar ratio, in all cases.

Regarding the stereochemistry of the new complexes, in all of them, the metal is a stereogenic centre and, therefore, two stereoisomers, epimers at the metal, can be obtained. The $R$ at carbon enantiomer of the cysteine-derived ligands was employed and we estimate that, due to the soft reaction conditions employed, no changes in the configuration at this carbon occur in the course of the reactions. Therefore, we assume that the configuration of the carbon of the modified cysteine is $R$ in all complexes. Notably, in complexes bearing $\kappa^{3} N, O, S$ coordinated cysteine derivatives, the $R$ configuration at carbon forces the metal to exclusively adopt the $R$ configuration. ${ }^{12}$ On the other hand, when the sulphur coordinates to the metal (compounds 1, 2, 5-9) two isomers with opposite configuration at sulphur could be formed. Additionally, in compounds $\mathbf{8}$ and $\mathbf{9}$, the nitrogen is also a stereogenic centre with two possible configurations.

Complexes with $\kappa^{2} N$,S coordination mode. No base has been added in the preparative reaction of complexes 1 and 2 . A broad peak in the ${ }^{1} \mathrm{H}$ NMR, centred at around $9.5 \mathrm{ppm}$ (complexes 1) or at around $6 \mathrm{ppm}$ (complexes 2), ${ }^{17}$ indicates that the proton of the carboxylic group was not dissociated. Consistently, the IR spectra present a very broad absorption centred at around $2950 \mathrm{~cm}^{-1}(v(\mathrm{OH}))$ and the carboxylic $v(\mathrm{C}=\mathrm{O})$ band appears in the $1715-1729 \mathrm{~cm}^{-1}$ range, $60-100 \mathrm{~cm}^{-1}$ shifted to greater energies than that of compounds 3-9 in which the carboxylic group is deprotonated (see Experimental section).

At room temperature, the NMR spectra of compounds 1a,b and 2a show two sharp sets of signals, in 92/8 (1a), 80/20 (1b) and 91/9 (2a) molar ratio, attributed to the $S_{\mathrm{M}}, R_{\mathrm{C}}$ and $R_{\mathrm{M}}, R_{\mathrm{C}}$ diastereomers. However, for complex $\mathbf{2} \mathbf{b}$ three sets of resonance signals, in 
64/27/9 molar ratio, were registered. We assume that in complexes 1 and 2 the sulphur is coordinated to the metal and, therefore, it is a stereogenic centre. For complexes 1a,b and 2a, either only one epimer at sulphur is obtained or both epimers quickly exchange in solution. However, for complex $\mathbf{2 b}$, probably the two epimers at sulphur either of the $S_{\mathrm{M}}, R_{\mathrm{C}}$ or of the $R_{\mathrm{M}}, R_{\mathrm{C}}$ isomer were observed.

Variable temperature proton NMR experiments, in the 298-213 K range, show an apparent broadening of the resonance signals in all cases but no splitting of the signals was observed even at the lowest temperature recorded and NOESY spectra were not informative about the stereochemistry of the compounds.

However, the circular dichroism (CD) spectra of the mixtures present a positive Cotton effect centred at around $340 \mathrm{~nm}$ for the iridium complexes and at around $360 \mathrm{~nm}$ for the ruthenium analogues. As we will comment later, the positive sign of this maximum is associated to an $S$ configuration at the metal centre and, therefore, the configuration of the major isomer of complexes 1 and $\mathbf{2}$ would be $S_{\mathrm{M}}, R_{\mathrm{C}}$.

Table 2. Chemical shift of the $\mathrm{C}_{5} \mathrm{Me}_{5}$ protons in the iridium complexes

\begin{tabular}{|c|c|c|c|}
\hline \multicolumn{2}{|c|}{$\kappa^{2}$-coordination } & \multicolumn{2}{c|}{$\kappa^{3}$-coordination } \\
\hline & $\delta\left(\mathrm{C}_{5} \mathrm{Me}_{5}\right)$ & & $\delta\left(\mathrm{C}_{5} \mathrm{Me}_{5}\right)$ \\
\hline $\mathbf{1 a}$ & $1.66,1.73$ & $\mathbf{6 a C l}$ & 1.87 \\
\hline $\mathbf{2 a}$ & $1.64,1.67$ & $\mathbf{7 a C l}$ & 1.88 \\
\hline $\mathbf{3 a}$ & $1.60,1.67$ & $\mathbf{6 a S b}$ & 1.92 \\
\hline $\mathbf{4 a}$ & $1.55,1.58$ & $\mathbf{7 a S b}$ & 1.84 \\
\hline $\mathbf{5 a}$ & $1.43,1.66,1.60,1.71$ & $\mathbf{8 a S b}$ & 1.84 \\
\hline & & $\mathbf{9 a}$ & 1.93 \\
\hline
\end{tabular}

The value of the $\mathrm{C}_{5} \mathrm{Me}_{5}$ protons chemical shift in complexes 1a and 2a, 1.64-1.73 ppm, is characteristic of a bidentate chelate coordination of the cysteine-derived ligands (Table 2). The carbon resonance of the methylene group bonded to the stereogenic carbon of the cysteine derivative $\left(\mathrm{CH}_{2} \mathrm{C}^{*}\right)$ appears at 36.76-38.83 ppm for the complexes with the HL1 ligand (1a,b) and at 38.71-45.27 ppm for the complexes with 
the modified cysteine HL2 (2a,b). These values were characteristic for the methylene group when it is engaged in a metallacyle ring (Table 3).

Table 3. Chemical shift of the methylene carbon $\mathrm{CH}_{2} \mathrm{C}^{*}$ and number of metallacycles in which the $\mathrm{CH}_{2} \mathrm{C}^{*}$ group is engaged

\begin{tabular}{|c|c|c|c|c|c|}
\hline \multirow[t]{12}{*}{ Ir } & & HL1 & HL2 & HL3 & $\begin{array}{c}\text { Number of } \\
\text { Metallacycles }\end{array}$ \\
\hline & $1 a$ & $36.76,38.83$ & -- & -- & 1 \\
\hline & $2 a$ & -- & $38.71,40.51$ & -- & 1 \\
\hline & $3 a$ & $40.66,41.05$ & -- & -- & 0 \\
\hline & $4 a$ & -- & $45.89,46.22$ & -- & 0 \\
\hline & $5 a$ & & & $34.67,37.56,35.02,37.03$ & 1 \\
\hline & $6 \mathrm{aCl}$ & 32.24 & -- & -- & 2 \\
\hline & 6aSb & 31.37 & -- & -- & 2 \\
\hline & $7 \mathrm{aCl}$ & -- & 36.47 & -- & 2 \\
\hline & $7 a S b$ & -- & 35.84 & -- & 2 \\
\hline & 8aSb & -- & -- & 28.13 & 2 \\
\hline & $9 a$ & -- & -- & 32.00 & 2 \\
\hline \multirow[t]{10}{*}{ Ru } & $1 \mathrm{~b}$ & $37.67,38.38$ & -- & -- & 1 \\
\hline & $2 b$ & -- & $39.91,44,35,45.27$ & -- & 1 \\
\hline & $3 b$ & 45.60 & -- & -- & 0 \\
\hline & $5 b$ & -- & -- & $33.48,33.48,35.69$ & 1 \\
\hline & $6 \mathrm{bCl}$ & 32.80 & -- & -- & 2 \\
\hline & $7 \mathrm{bCl}$ & -- & $37.70,36.75$ & -- & 2 \\
\hline & $6 \mathrm{bSb}$ & 31.05 & -- & -- & 2 \\
\hline & 7bSb & -- & 35.98 & -- & 2 \\
\hline & $8 b S b$ & -- & -- & 31.81 & 2 \\
\hline & $9 b$ & -- & -- & $32.57,33.44$ & 2 \\
\hline
\end{tabular}

Reaction of complexes 1 and 2 with $\mathrm{NaHCO}_{3}$. The carboxylic group of compounds 1 and 2 can be deprotonated with $\mathrm{NaHCO}_{3}$. Formally, the resulting carboxylate group displaces the chloride from the coordination sphere of the metal giving rise to the $\kappa^{3} N, O, S$ coordinated cationic complexes $\mathbf{6 C l}$ and $7 \mathbf{C l}$. These complexes are in equilibrium with the corresponding $\kappa^{2} N, O$ neutral compounds $\mathbf{3}$ and $\mathbf{4}$ in which the chloride replaces the coordinated SBn arm in complexes $\mathbf{6 C l}$ and $\mathbf{7 C l}$ (Eq. 1). In the Table of Eq. 1, the relative amounts of neutral and cationic complexes, the isomeric composition and configuration of the obtained mixtures, in chloroform, are shown.

For the iridium complexes, NMR measurements at room temperature indicate that the two epimers at the metal of the $\kappa^{2} N, O$ complexes 3a and $4 \mathbf{a}$ were present in 90/10 and 89/11 molar ratio, respectively. Under the same conditions, only the $R_{\mathrm{Ir}}, R_{\mathrm{C}}$ isomer 
of the cationic complexes $\mathbf{6 a C l}$ and $7 \mathbf{a C l}$ was detected. If present, the epimers at the sulphur were not resolved even at $193 \mathrm{~K}$.

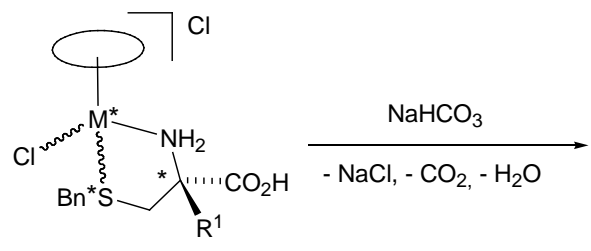

1, 2

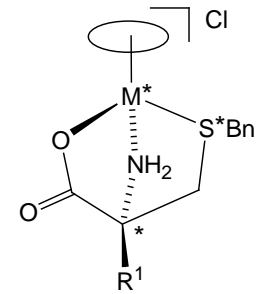

$6 \mathrm{Cl}, 7 \mathrm{Cl}$

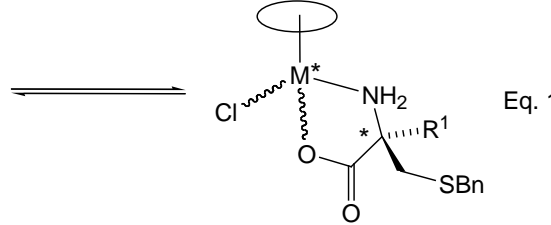

3, 4

$\bigcap \mathrm{M}=\left(\eta^{5}-\mathrm{C}_{5} \mathrm{Me}_{5}\right) \mathrm{Ir},\left(\eta^{6}-p-\mathrm{MeC}_{6} \mathrm{H}_{4} \mathrm{PPr}\right) \mathrm{Ru}$

\begin{tabular}{|c|c|c|c|}
\hline $\mathrm{M}$ & $\mathrm{R}^{1}$ & \multicolumn{2}{|c|}{ Compounds, Composition and Configuration } \\
\hline Ir & $\mathrm{H}$ & $\mathbf{3 a}(91 \%)$ & $\mathbf{6 a C l}(9 \%)$ \\
& & $S_{\mathrm{lr}}, R_{\mathrm{C}}(90 \%) / R_{\mathrm{lr}}, R_{\mathrm{C}}(10 \%)$ & $R_{\mathrm{lr}}, R_{\mathrm{C}}$ \\
\hline $\mathrm{Ru}$ & $\mathrm{H}$ & $\mathbf{3 b}(4 \%)$ & $\mathbf{6 b C l}(96 \%)$ \\
& & $S_{\mathrm{Ru}}, R_{\mathrm{C}}$ & $R_{\mathrm{Ru}}, R_{\mathrm{C}}, S_{\mathrm{S}}(96 \%) / R_{\mathrm{Ru}}, R_{\mathrm{C}}, R_{\mathrm{S}}(4 \%)$ \\
\hline Ir & $\mathrm{Me}$ & $\mathbf{4 a}(54 \%)$ & $\mathbf{7 a C l}(46 \%)$ \\
& & $S_{\mathrm{lr}}, R_{\mathrm{C}}(89 \%) / R_{\mathrm{lr}}, R_{\mathrm{C}}(11 \%)$ & $R_{\mathrm{lr}}, R_{\mathrm{C}}$ \\
\hline $\mathrm{Ru}$ & $\mathrm{Me}$ & $\mathbf{4 b}$ & $\mathbf{7 b C l}(100 \%)$ \\
& & Not detected & $R_{\mathrm{Ru}}, R_{\mathrm{C}}, S_{\mathrm{S}}(96 \%) / R_{\mathrm{Ru}}, R_{\mathrm{C}}, R_{\mathrm{S}}(4 \%)$ \\
\hline
\end{tabular}

Solvent: $\mathrm{CDCl}_{3}$

For the ruthenium complexes, a small amount of a single epimer at the metal of $\mathbf{3 b}$ (4\%) was present in $\mathrm{CDCl}_{3}$, at room temperature. The amount of the other metal epimer should be negligible. For the methylated cysteine-derived ligand HL2, the presence of the corresponding bidentate chelate complex $\mathbf{4 b}$ can be excluded because the composition of the mixture, that depends on the solvent (see below), does not change significantly in $\mathrm{CD}_{3} \mathrm{OD}$. Under the same conditions, the two epimers at sulphur were observed for the cationic tripodal complexes $\mathbf{6 b C l}$ and $\mathbf{7 b C l}$ in 96/4 molar ratio in both cases. Most probably, the $S$ at sulphur diastereomer, for which less steric hindrance between the $\mathrm{C}_{5} \mathrm{Me}_{5}$ and $\mathrm{Bn}$ groups is expected, was the most abundant isomer.

In acetone, the $C D$ spectrum of the $\mathbf{3 a} / \mathbf{6 a C l}$ mixtures showed a positive Cotton effect centred at $344 \mathrm{~nm}$. However, negative maxima at 334 and $332 \mathrm{~nm}$ were recorded 
for $\mathbf{3 b} / \mathbf{6 b C l}$ mixtures and $\mathbf{7 b C l}$, respectively. As free $\alpha$-amino acids do not show Cotton effects above $230 \mathrm{~nm},{ }^{18}$ this absorption was tentatively assigned to transitions associated to the metal. On the other hand, the major isomer of the iridium complex $\mathbf{4 a}$ shows a NOESY relationship between one of the $\mathrm{CH}_{2} \mathrm{Ph}$ methylene protons and the $\mathrm{C}_{5} \mathrm{Me}_{5}$ protons indicating that the configuration at iridium is $S$. Taking into account all these observations, we propose the $S_{\text {Ir }}$ configuration to the major epimer of the complex $3 a$.

As it can be seen in the Table of Equation 1, the composition of the mixtures strongly depends on the metal, the cysteine derivative and the solvent employed. Thus, the amount of cationic compound is greater for the ruthenium complexes than for the corresponding iridium ones, the equilibrium is shifted to the left when the methylated cysteine-derived ligand $\mathbf{H L} 2\left(\mathrm{R}^{1}=\mathrm{Me}\right)$ replaces cysteine derivative $\mathbf{H L 1}\left(\mathrm{R}^{1}=\mathrm{H}\right)$ and, as expected, the relative concentration of the cationic chlorides $\mathbf{6 C l}$ and $\mathbf{7 C l}$ is higher in methanol than in chloroform.

Thus, for example, while a $\mathbf{3 a / 6 a C l}$ molar ratio of 91/9 was measured in chloroform for iridium complexes, for the ruthenium analogues only a $4 \%$ of $\mathbf{3 b}$ was measured in the mixture with $\mathbf{6 b C l}$. As complex $\mathbf{4 b}$ was not detected in chloroform, we assume that, in this solvent, the equilibrium of a mixture of the methylated cysteine derivative ruthenium complexes $\mathbf{4 b}$ and $\mathbf{7 b C l}$ is completely shifted to the left (Eq. 1). Regarding the solvents, for mixtures $3 \mathbf{a} / \mathbf{6 a C l}$ and $\mathbf{4 a / 7 a C l}$ molar ratios of $91 / 9$ and 54/46 were measured in chloroform; these ratios decrease to 39/61 and 16/84, respectively, in a polar solvent such as methanol.

In the iridium compounds, the $\mathrm{C}_{5} \mathrm{Me}_{5}$ proton resonance was affected by the coordination mode. While in the tripodal compounds $\mathbf{6 a C l}$ and $\mathbf{7 a C l}$ this signal appears near of $1.90 \mathrm{ppm}$, in the bidentate chelate complexes $\mathbf{3 a}$ and $\mathbf{4 a}$ these protons resonate at 
about $1.60 \mathrm{ppm}$, a value comparable to those measured for the also bidentate chelate complexes 1a and 2a (Table 2).

The chemical shift of the $\mathrm{CH}_{2} \mathrm{C}^{*}$ methylene carbon is strongly affected by the coordination mode. Thus, while in the $\kappa^{3} N, O, S$ complexes $\mathbf{6 a C l}$ and $\mathbf{6 b C l}$, in which this group is included in the M-O-C-C-N and M-S-C-C-N metallacycles, it appears at about $32.5 \mathrm{ppm}$, in the $\kappa^{2} N, O$ compounds $\mathbf{3}$ and $\mathbf{4 a}$, in which this methylene group is pendant, it resonates from 40.66 to $46.22 \mathrm{ppm}$ (Table 3). An intermediate value of the chemical sift was encountered when this methylene is included only in one metallacycle, as it is the case of compounds $\mathbf{1}$ and $\mathbf{2}$ (Table 3).

Reactions with $\mathbf{H L} \mathbf{3}$ in basic medium. Complexes $\mathbf{5 a}$ and $\mathbf{5 b}$ were prepared by reacting the dimers $\left[\left\{\left(\eta^{\mathrm{n}} \text {-ring) } \mathrm{MCl}\right\}_{2}(\mu-\mathrm{Cl})_{2}\right]\right.$ with $\mathbf{H L 3}$ in the presence of one equivalent of $\mathrm{NaHCO}_{3}$.

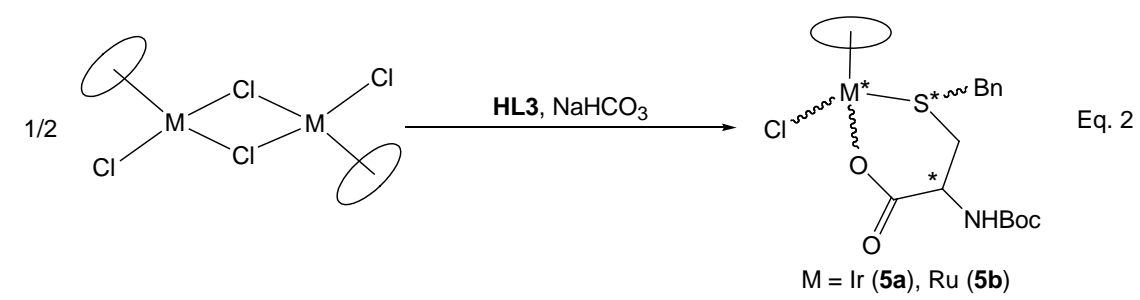

In these complexes, the metal, the asymmetric carbon of the cysteine derivative and the sulphur atom are stereogenic centres. As the configuration at the carbon is fixed, four diastereomers are possible. In fact, the four isomers were isolated for the iridium complex 5a, in 62/21/9/8 molar ratio, and three isomers in 64/27/9 molar ratio were obtained for the ruthenium complex $5 \mathbf{b}$.

The $v(C O)$ frequency, 1630 and $1622 \mathrm{~cm}^{-1}$ for $\mathbf{5 a}$ and $\mathbf{5 b}$, respectively, suggests a monodentate coordination for the carboxylate group. The values of the chemical shift of the $\mathrm{C}_{5} \mathrm{Me}_{5}$ protons in $\mathbf{5 a}, 1.43-1.71 \mathrm{ppm}$, indicated a bidentate chelate coordination for the amino carboxylate ligand (Table 2). The $\mathrm{CH}_{2} \mathrm{C}^{*}$ methylene carbon is deshielded 
with respect to the analogue methylene carbon in the corresponding tripodal complexes $\mathbf{8 a S b}$ and $\mathbf{8 b S b}$ (Table 3).

All these spectroscopic data pointed to a $\kappa^{2} O, S$ coordination mode for the amino carboxylate in complexes 5. Most probably, coordination of the nitrogen is inhibited sterically, by the presence of the bulky Boc substituent, as well as electronically, by delocalization of the nitrogen electron pair by conjugation to the $\mathrm{CO}$ double bond.

A NOE enhancement was observed in the $\mathrm{C}_{5} \mathrm{Me}_{5}$ protons of the major isomer of the iridium complex 5a when the pro- $\mathrm{R}$ proton of the $\mathrm{CH}_{2} \mathrm{C}^{*}$ group was irradiated. This NOE relationship suggests that the configuration at the iridium in this isomer is $S$.

No relevant changes have been observed in the NMR spectra of the complexes from 298 to $193 \mathrm{~K}$.

Chloride abstraction in complexes 3-5. Addition of $\mathrm{AgSbF}_{6}$ to solutions of mixtures of $\mathbf{3}$ and $\mathbf{6 C l}$ or $\mathbf{4}$ and $\mathbf{7 C l}$ or pure $\mathbf{5}$ afforded the cationic complexes $\mathbf{6 S b}-\mathbf{8 S b}$ in which the cysteine-based ligand featured a $\kappa^{3} N, O, S$ coordination mode (Scheme 1, Eq. 3). The iridium complex $\mathbf{8 a S b}$ was alternatively prepared by reacting $\left[\left\{\left(\eta^{5}-\mathrm{C}_{5} \mathrm{Me}_{5}\right) \operatorname{IrCl}\right\}_{2}(\mu-\right.$ $\mathrm{Cl})_{2}$ ] with 4 equivalents of $\mathrm{AgSbF}_{6}$ and subsequent addition of $\mathbf{H L 3}$ in the presence of $\mathrm{NaHCO}_{3}$.

Compounds $\mathbf{6 S b}$ and $7 \mathrm{Sb}$ contain three stereogenic centres: the metal, the asymmetric carbon of the cysteine derivative and the sulphur atom. As stated above, in half-sandwich bearing $\kappa^{3} N, O, S$ coordinated $(R)$-cysteine derivatives, the only possible configuration for the metal is $R$. Therefore, two diastereomers, epimers at sulphur, namely $R_{\mathrm{M}}, R_{\mathrm{C}}, R_{\mathrm{S}}$ and $R_{\mathrm{M}}, R_{\mathrm{C}}, S_{\mathrm{S}}$, could be obtained. ${ }^{19}$

In the temperature range 298-193 K, the NMR spectra of the iridium complexes $\mathbf{6 a S b}$ and $7 \mathbf{a S b}$ consisted of only one set of resonance signals. Therefore, either the 
sulphur only adopts one configuration or both epimers at sulphur quickly exchange even at $193 \mathrm{~K}$. The configuration at sulphur of solid $\mathbf{6 a S b}$, determined by diffractometric methods, is $S$ (see above). However, for their ruthenium counterparts $\mathbf{6 b S b}$ and $\mathbf{7 b S b}$, the NMR spectra revealed that, in solution, the two epimers at sulphur $R_{\mathrm{M}}, R_{\mathrm{C}}, S_{\mathrm{S}}$ and $R_{\mathrm{M}}, R_{\mathrm{C}}, R_{\mathrm{S}}$ were present. From steric grounds we propose that the less abundant isomer (5 $\%$ in $\mathbf{6 b S b}$ and less than $3 \%$ in $\mathbf{7 b S b}$ ) was the $R$ at sulphur diastereomer.

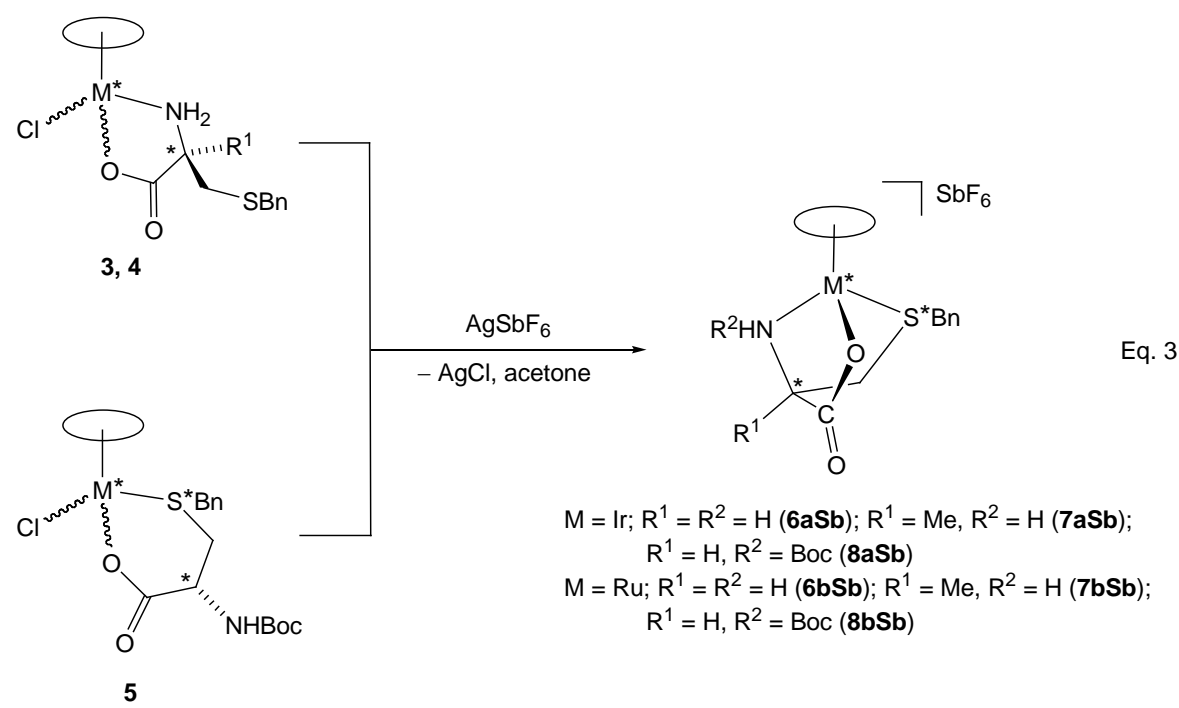

Again, the NBoc containing compounds $\mathbf{8 a S b}$ and $\mathbf{8 b S b}$ behaved differently. In spite of the nitrogen also being a stereocentre, only one stereoisomer was obtained. Furthermore, in solution, hydrolysis of the Boc moiety renders small amounts of $\mathbf{6 a S b}$ (about $8 \%$ ) and of $\mathbf{6 b S b}$ (about $10 \%$ ), respectively. Additionally, about $18 \%$ of other compound has been detected by NMR. Probably, this compound is the solvated complex in which a solvent molecule occupies the vacant site resulting from the decoordination of the NBoc arm of the cysteine derivative in $\mathbf{8 a S b}$. In fact, after addition of MeCN (30 equiv.) to a dichloromethane solution of the mixture, the percentage of this compound increases from 18 to $25 \%$.

The chemical shift of the $\mathrm{C}_{5} \mathrm{Me}_{5}$ protons in the iridium compounds $\mathbf{6 a S b} \mathbf{b a S b}$ (1.84-1.92 ppm, Table 2) indicated a $\kappa^{3} N, O, S$ coordination for the cysteine-derived 
ligands and the strong shielding measured for the $\mathrm{CH}_{2} \mathrm{C}^{*}$ methylene carbon in complexes 6 and $\mathbf{7}$ with respect to $\mathbf{3}$ and $\mathbf{4 a}$ (more than 8 ppm, Table 3) was attributed to the inclusion of this carbon into the M-N-C-C-S and M-O-C-C-C-S metallacycles.

Deprotonation of complexes 8 . Treatment of the complexes $\mathbf{8 a S b}$ and $\mathbf{8 b S b}$ with $\mathrm{NaHCO}_{3}$ afforded the corresponding neutral deprotonated compounds $\mathbf{9 a}$ and $\mathbf{9 b}$. These complexes can also be prepared treating the dimers $\left[\left\{\left(\eta^{\mathrm{n}} \text {-ring }\right) \mathrm{MCl}\right\}_{2}(\mu-\mathrm{Cl})_{2}\right]$ with $\mathbf{H L} 3$ in the presence of 2 equiv. of $\mathrm{NaHCO}_{3}$ (Eq. 4).

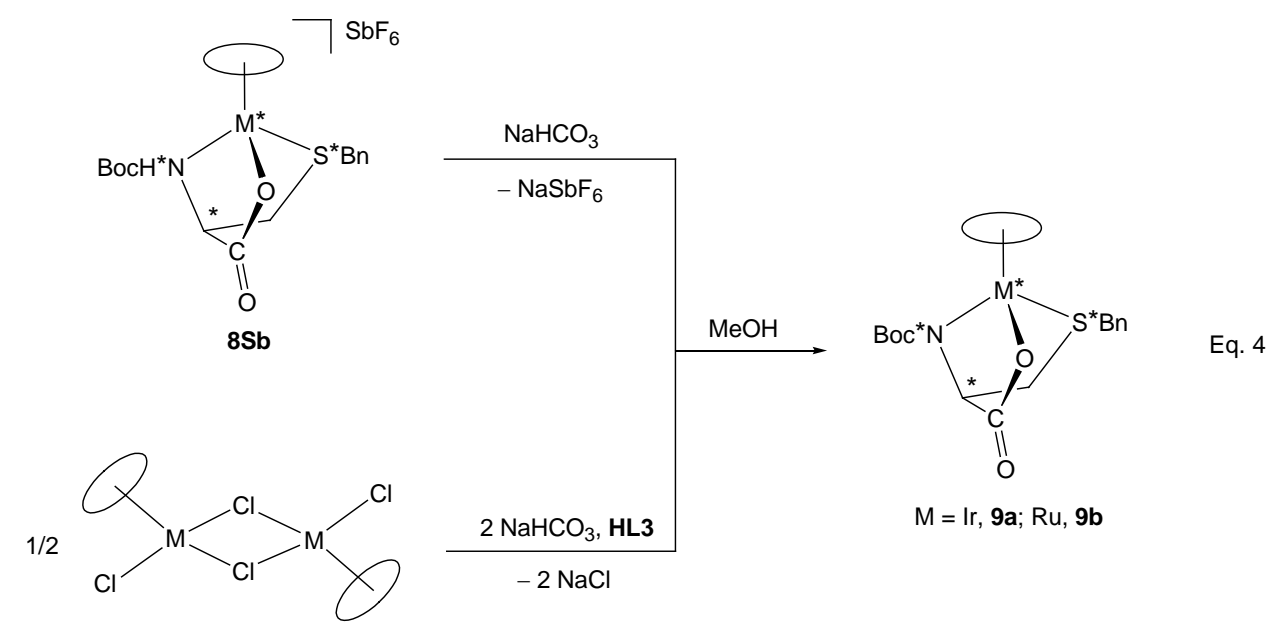

At $298 \mathrm{~K}$, the proton and carbon NMR spectra of complex 9a consist of only one set of sharp peaks but two sets of peaks in 68/32 molar ratio were observed for $\mathbf{9 b}$, at the same temperature.

The CD spectrum of complex 9a presents a negative maximum centred at $352 \mathrm{~nm}$ assigned to an $R$ configuration at the metal.

The chemical shift of the $\mathrm{C}_{5} \mathrm{Me}_{5}$ protons in $9 \mathbf{a}(1.93 \mathrm{ppm})$ and that of the $\mathrm{CH}_{2} \mathrm{C}^{*}$ methylene carbon in both compounds (32.00 ppm, 9a and 32.57 and 33.44 ppm, 9b) strongly suggest that, in the reaction, the $\kappa^{3} N, O, S$ coordination mode has been retained and that, therefore, the configuration at both metal and cysteine-derived ligand carbon is $R$. However, the nitrogen and the sulphur atoms are also stereogenic centres and, as only 
one or two isomers were detected at $298 \mathrm{~K}$, most probably the complexes undergo equilibrating processes in solution at this temperature. At this respect, the recently reported crystal structure of the rhodium analogue ${ }^{12}\left[\left(\eta^{5}-\mathrm{C}_{5} \mathrm{Me}_{5}\right) \mathrm{Rh}\left(\kappa^{3} N, O, S-\mathbf{L} \mathbf{3}_{\mathbf{H}}\right)\right]$ reveals that the nitrogen adopts an almost planar geometry and DFT calculations showed a very low energy transition state for the epimerization process at this atom. Probably, a consequence of the planarization is the shift of ca. 5 ppm to low field of the resonance of the asymmetric carbon, $\mathrm{C}^{*}$, adjacent to the nitrogen, with respect to that of the related protonated complex $\left[\left(\eta^{5}-\mathrm{C}_{5} \mathrm{Me}_{5}\right) \mathrm{Rh}\left(\kappa^{3} N, O, S-\mathbf{L} 3\right]^{+12}\right.$ In fact, a similar deshielding was observed for this carbon in complexes $9 \mathbf{a}(\Delta \delta=4.6 \mathrm{ppm})$ and $9 \mathbf{b}(\Delta \delta=$ $6.6 \mathrm{ppm})$. Hence, we argue that also in complexes 9 inversion at nitrogen is low energydemanding and that the observed isomers for $\mathbf{9 b}$ are the two epimers at sulphur which, in turn, can be also observed for the iridium complex, by lowering temperature. ${ }^{19}$

To verify this issue, a variable temperature NMR study, in the range 298-183K, was undertaken for complex 9a. The singlet attributed to the $t \mathrm{Bu}$ substituent of the Boc, which resonates at $1.39 \mathrm{ppm}$ at $298 \mathrm{~K}$, was taken as reference. On cooling, this singlet broadens out, coalesces at about $264 \mathrm{~K}$ and splits into two differently populated signals (85/15 ratio) below $238 \mathrm{~K}$. The low temperature limiting spectrum was achieved at 193 $\mathrm{K}$. The process obeys a first-order rate law, with derived activation parameters at $293 \mathrm{~K}$ of $\Delta \mathrm{H}^{\#}=-0.55 \pm 0.03 \mathrm{kcal} \cdot \mathrm{mol}^{-1}, \Delta \mathrm{S}^{\#}=-44.3 \pm 6.0 \mathrm{cal} \cdot \mathrm{mol}^{-1} \cdot \mathrm{K}^{-1}$ and $\Delta \mathrm{G}^{\#}=12.4 \pm$ $2.3 \mathrm{kcal} \cdot \mathrm{mol}^{-1}$ (see ESI†). These values are very similar to those recently reported for the rhodium analogue. In particular, the relatively high negative value measured for $\Delta \mathrm{S}^{\neq}$ indicate that the epimerisation at sulphur could take place through an associative mechanism identical to that calculated for the rhodium analogue: de-coordination of sulphur, coordination of a solvent molecule, turning around the C-S bond, decoordination of the solvent molecule and re-coordination of sulphur. ${ }^{12}$ 
In summary, while the $R_{\mathrm{Ir}}, R_{\mathrm{C}}, S_{\mathrm{S}}$ and $R_{\mathrm{Ir}}, R_{\mathrm{C}}, R_{\mathrm{S}}$ diastereomers of complex 9a were quickly exchanging at $298 \mathrm{~K}$, the corresponding isomers of complex $\mathbf{9 b}$ can be separately observed at this temperature. These data suggest again that epimerization at sulphur is more energy-demanding in the ruthenium complex. For steric grounds, in both cases, the most abundant isomer would be the $S$ at sulphur epimer (see above).

\section{Conclusions}

Cysteine derivatives HL1, HL2 and HL3 display a variety of coordination modes towards $\left(\eta^{5}-\mathrm{C}_{5} \mathrm{Me}_{5}\right) \mathrm{Ir}$ and $\left(\eta^{6}-p-\mathrm{MeC}_{6} \mathrm{H}_{4} i \mathrm{Pr}\right) \mathrm{Ru}$ moieties. Examples of neutral $\kappa^{2} N, S$, monoanionic $\kappa^{2} N, O, \kappa^{2} S, O$ and $\kappa^{3} N, O, S$, as well as, dianionic $\kappa^{3} N, O, S$ have been shown. The metal, the asymmetric carbon of the cysteine derivative and, in some instances, the sulphur and the nitrogen atoms are stereogenic centres. In most cases, the absolute configuration of the complexes has been determined, in solution, by NMR and CD spectrocopies and for $\mathbf{6 a S b}$, in the solid state by diffractometric methods. In the iridium complexes, the chemical shift of the $\mathrm{C}_{5} \mathrm{Me}_{5}$ protons discriminates between $\kappa^{2}$ and $\kappa^{3}$ coordination modes. The chemical shift of the $\mathrm{CH}_{2} \mathrm{C}^{*}$ methylene carbon is a useful diagnostic for the inclusion of this group into metallacycles. In complexes in which the cysteine-based ligand is $\kappa^{3}$ coordinated, the metal adopts exclusively the same configuration than the carbon of the cysteine derivative with the subsequent reduction of the number of possible isomers. The configuration at sulphur is governed by the steric hindrance between the $\mathrm{C}_{5} \mathrm{Me}_{5}$ and benzyl substituents within the formed metallacycles and epimerization at sulphur is less energy-demanding for the iridium complexes than for the ruthenium analogues. Finally, in the iridium complex 9a, the thermodynamic parameters for the epimerization at sulphur have been determined by variable temperature proton NMR measurements. 


\section{Experimental section}

\section{General information}

General Comments. All preparations have been carried out under argon. All solvents were treated in a PS-400-6 Innovative Technologies Solvent Purification System (SPS) and degassed prior to use. Infrared spectra were recorded on Perkin-Elmer Spectrum100 (ATR mode) FT-IR spectrometer. Carbon, hydrogen, nitrogen and sulphur analyses were performed using a Perkin-Elmer $240 \mathrm{~B}$ microanalyzer. ${ }^{1} \mathrm{H}$ and ${ }^{13} \mathrm{C}$ spectra were recorded on a Bruker AV-300 (300.13 MHz), a Bruker AV-400 (400.16 MHz) or a Bruker AV-500 (500.13 MHz) spectrometers. In both, ${ }^{1} \mathrm{H}$ NMR and ${ }^{13} \mathrm{C} \mathrm{NMR}$ measurements the chemical shifts are expressed in ppm downfield from $\mathrm{SiMe}_{4} . J$ values are given in Hz. COSY, NOESY, HSQC, HMQC and HMBC ${ }^{1} \mathrm{H}-\mathrm{X}\left(\mathrm{X}={ }^{1} \mathrm{H},{ }^{13} \mathrm{C}\right)$ correlation spectra were obtained using standard procedures. CD spectra were determined in acetone (ca. $5 \times 10^{-4} \mathrm{~mol} \mathrm{~L}^{-1}$ solutions) in a $1 \mathrm{~cm}$ path length cell by using a JASCO J-810 spectropolarimeter. Cysteine derivatives HL1 and HL3 are commercially available from Acros and Aldrich, respectively. Cysteine-based ligand HL2 was prepared as reported in ref. 12.

Preparation of the complexes $\left[\left(\eta^{5}-\mathrm{C}_{5} \mathrm{Me}_{5}\right) \operatorname{IrCl}\left(\kappa^{2} N, S-\mathrm{HL}\right)\right] \mathrm{Cl},(\mathrm{HL}=\mathrm{HL1}$ (1a), HL2 (2a) and $\left[\left(\eta^{6}-p-\mathrm{MeC}_{6} \mathrm{H}_{4} i \mathrm{Pr}\right) \operatorname{RuCl}\left(\kappa^{2} N, S-H L\right)\right] C l$, (HL = HL1 (1b), HL2 (2b)). At room temperature, to a suspension of the corresponding dimer $\left[\left\{\left(\eta^{\mathrm{n}}-\text { ring }\right) \mathrm{MCl}\right\}_{2}(\mu\right.$ $\mathrm{Cl})_{2}$ ] $(0.16 \mathrm{mmol})$, in $10 \mathrm{~mL}$ of $\mathrm{CH}_{3} \mathrm{OH}, 0.32 \mathrm{mmol}$ of the corresponding cysteine derivative were added. The resulting yellow solution was stirred for $1 \mathrm{~h}$ and then was filtered to remove any insoluble material. The solution was concentrated under reduced pressure to ca. $1 \mathrm{~mL}$. The slow addition of $\mathrm{Et}_{2} \mathrm{O}$ led to the precipitation of a yellow solid which was washed with $\mathrm{Et}_{2} \mathrm{O}(3 \times 5 \mathrm{~mL})$ and vacuum-dried. 
[( $\left.\left.\eta^{5}-\mathrm{C}_{5} \mathbf{M e}_{5}\right) \operatorname{IrCl}\left(\boldsymbol{\kappa}^{2} \boldsymbol{N}, \boldsymbol{S}-\mathbf{H L 1}\right)\right] \mathrm{Cl}$ (1a). Yield: $74 \%$. Diastereomeric ratio: 92/8. Anal. calcd for $\mathrm{C}_{20} \mathrm{H}_{28} \mathrm{Cl}_{2} \mathrm{IrNO}_{2} \mathrm{~S}$, \%: C, 39.4; H, 4.6; N, 2.3; S, 5.3. Found, \%: C, 39.4; H,

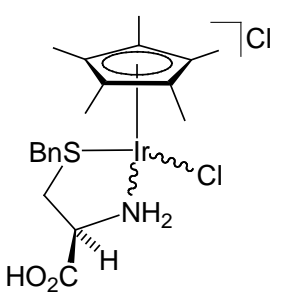

4.8; N, 2.2; S, 5.3. IR (solid, $\mathrm{cm}^{-1}$ ): $v(\mathrm{OH}) 2916$ (vbr), $v(\mathrm{C}=\mathrm{O}) 1724$

(s). CD (acetone, $\left.5.1 \times 10^{-4} \mathrm{M}, 298 \mathrm{~K}\right): \lambda$, nm, $(\Delta \varepsilon): 341(+4.34)$.

$S_{\mathrm{Ir}}, R_{\mathrm{C}}$ diastereomer (92\%). ${ }^{1} \mathrm{H} \mathrm{NMR}\left(500.13 \mathrm{MHz}, \mathrm{CD}_{2} \mathrm{Cl}_{2}, 298 \mathrm{~K}\right.$, ppm): $\delta 10.6$ - 8.9 (vbr, 1H, OH), $7.68-7.20\left(2 \times \mathrm{m}, 5 \mathrm{H}, \mathrm{H}_{\mathrm{Ar}}\right), 6.80(\mathrm{pt}, J=9.7 \mathrm{~Hz}, 1 \mathrm{H}$, NH), $4.98(\mathrm{~d}, J=8.9 \mathrm{~Hz}, 1 \mathrm{H}, \mathrm{NH}), 4.78\left(\mathrm{AB}\right.$ system, $\left.J_{\mathrm{AB}}=11.1 \mathrm{~Hz}, 2 \mathrm{H}, \mathrm{CH}_{2} \mathrm{Ph}\right), 4.22$ (m, 1H, C ${ }^{*} \mathrm{H}$ ), $3.57\left(\mathrm{ABXX}\right.$ ' system, $J_{\mathrm{AB}}=13.3, J_{\mathrm{AX}}=10.9, J_{\mathrm{AX}}=3.1 \mathrm{~Hz}, 2 \mathrm{H}, \mathrm{CH}_{2} \mathrm{C}^{*}$ ), 1.66 (s, 15H, C $\left.{ }_{5} \mathrm{Me}_{5}\right) .{ }^{13} C\left\{{ }^{1} \mathrm{H}\right\} \mathrm{NMR}\left(125.8 \mathrm{MHz}, \mathrm{CD}_{2} \mathrm{Cl}_{2}, 298 \mathrm{~K}, \mathrm{ppm}\right): \delta 170.11$ $(\mathrm{C}=\mathrm{O}), 133.49, \quad 130.85,128.75,128.46\left(\mathrm{C}_{\mathrm{Ar}}\right), 91.27\left(C_{5} \mathrm{Me}_{5}\right), 60.37\left(\mathrm{C}^{*}\right), 38.48$ $\left(\mathrm{CH}_{2} \mathrm{Ph}\right), 36.76\left(\mathrm{CH}_{2} \mathrm{C}^{*}\right), 8.46\left(\mathrm{C}_{5} \mathrm{Me}_{5}\right)$.

$R_{\mathrm{II}}, R_{\mathrm{C}}$ diastereomer (8 \%). ${ }^{1} \mathrm{H} \mathrm{NMR}\left(500.13 \mathrm{MHz}, \mathrm{CD}_{2} \mathrm{Cl}_{2}, 298 \mathrm{~K}, \mathrm{ppm}\right): \delta 7.68-7.20$ (2 $\times$ m, 5H, $\left.\mathrm{H}_{\mathrm{Ar}}\right), 4.51\left(\mathrm{~d}, J_{\mathrm{AB}}=11.8 \mathrm{~Hz}, 1 \mathrm{H}, \mathrm{CH}_{2} \mathrm{Ph}\right), 4.20\left(1 \mathrm{H}, \mathrm{CH}_{2} \mathrm{Ph}\right), 3.76(\mathrm{~m}, 1 \mathrm{H}$, $\mathrm{C}^{*} \mathrm{H}$ ), $3.41\left(\mathrm{~m}, 1 \mathrm{H}, \mathrm{CH}_{2} \mathrm{C}^{*}\right.$ ), 2.72 (pt, $11.9 \mathrm{~Hz}, 1 \mathrm{H}, \mathrm{CH}_{2} \mathrm{C}^{*}$ ), 1.73 (s, 15H, $\mathrm{C}_{5} \mathrm{Me}_{5}$ ). ${ }^{13} C\left\{{ }^{1} H\right\} N M R\left(125.8 \mathrm{MHz}, \mathrm{CD}_{2} \mathrm{Cl}_{2}, 298 \mathrm{~K}, \mathrm{ppm}\right): \delta 170.44(\mathrm{C}=\mathrm{O}), 133.23,130.46$, 128.95, $128.44\left(\mathrm{C}_{\mathrm{Ar}}\right), 91.61\left(\mathrm{C}_{5} \mathrm{Me}_{5}\right), 61.01\left(\mathrm{C}^{*}\right), 39.68\left(\mathrm{CH}_{2} \mathrm{Ph}\right), 38.83\left(\mathrm{CH}_{2} \mathrm{C}^{*}\right), 8.84$ $\left(\mathrm{C}_{5} M e_{5}\right)$.

$\left[\left(\eta^{6}-p-M_{6} \mathbf{H}_{4} i \mathrm{Pr}\right) \operatorname{RuCl}\left(\boldsymbol{\kappa}^{2} \boldsymbol{N}, \boldsymbol{S}-\mathbf{H L 1}\right)\right] \mathrm{Cl}$ (1b). Yield: 85 \%. Diastereomeric ratio: 80/20. Anal. calcd for $\mathrm{C}_{20} \mathrm{H}_{27} \mathrm{Cl}_{2} \mathrm{NO}_{2} \mathrm{RuS}$, \%: C, 44.9; H, 5.5; N, 2.6; S, 6.0. Found, \%: C, 45.2; H, 5.8; N, 2.6; S, 6.1. IR (solid, $\mathrm{cm}^{-1}$ ): $v(\mathrm{OH}) 2963$ (vbr), $v(\mathrm{C}=\mathrm{O}) 1721$ (s). CD (acetone, $\left.5.0 \times 10^{-4} \mathrm{M}, 298 \mathrm{~K}\right): \lambda, \mathrm{nm},(\Delta \varepsilon): 358(+2.49)$.

$S_{\mathrm{Ru}}, R_{\mathrm{C}}$ diastereomer (80 \%). ${ }^{1} \mathrm{H} \mathrm{NMR}\left(500.13 \mathrm{MHz}, \mathrm{CD}_{2} \mathrm{Cl}_{2}, 298 \mathrm{~K}, \mathrm{ppm}\right): \delta 10.0-8.2$ (vbr, 1H, OH), 7.76 - 7.22 (m, 5H, $\mathrm{H}_{\mathrm{Ar}}$ ), 7.14 (brs, 1H, NH), 5.97, 5.65, 5.34, 4.97 (4 × d, $\left.J=5.6 \mathrm{~Hz}, 4 \mathrm{H}, \mathrm{H}_{\mathrm{A}}, \mathrm{H}_{\mathrm{B}}, \mathrm{H}_{\mathrm{A}^{\prime}}, \mathrm{H}_{\mathrm{B}^{\prime}}\right), 4.39\left(\mathrm{AB}\right.$ system, $\left.J_{\mathrm{AB}}=11.2 \mathrm{~Hz}, 2 \mathrm{H}, \mathrm{CH}_{2} \mathrm{Ph}\right), 4.15$ (m, 1H, C ${ }^{*} \mathrm{H}$ ), 4.08 (br, 1H, NH), $2.53\left(\mathrm{ABXX}\right.$ ' system, $J_{\mathrm{AB}}=12.7, J_{\mathrm{AX}}=7.3, J_{\mathrm{AX}}=4.5$ 


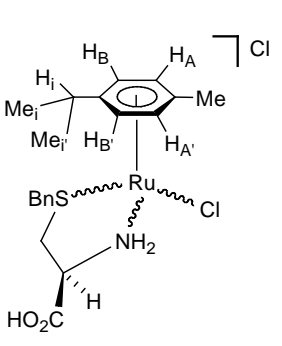

$\mathrm{Hz}, 2 \mathrm{H}, \mathrm{CH}_{2} \mathrm{C}^{*}$ ), 2.87 (sept, $J=6.7 \mathrm{~Hz}, 1 \mathrm{H}, \mathrm{H}_{\mathrm{i}}$ ), 1.99 (s, 3H, Me), $1.28\left(\mathrm{~d}, J=6.7 \mathrm{~Hz}, 6 \mathrm{H}, \mathrm{Me}_{\mathrm{i}}, \mathrm{Me}_{\mathrm{i}}\right) .{ }^{13} \mathrm{C}\left\{{ }^{1} \mathrm{H}\right\} N M R(125.8 \mathrm{MHz}$, $\left.\mathrm{CD}_{2} \mathrm{Cl}_{2}, 298 \mathrm{~K}, \mathrm{ppm}\right): \delta 169.81(\mathrm{C}=\mathrm{O}), 134.02,130.59,128.77$, $128.68\left(\mathrm{C}_{\mathrm{Ar}}\right), 110.91,98.76\left(\mathrm{C}_{p \text {-cymene }}\right), 84.83,84.61,84.05,83.64$ $\left(\mathrm{CH}_{\mathrm{A}}, \mathrm{CH}_{\mathrm{B}}, \mathrm{CH}_{\mathrm{A}^{\prime}}, \mathrm{CH}_{\mathrm{B}^{\prime}}\right), 57.70\left(\mathrm{C}^{*}\right), 37.86\left(\mathrm{CH}_{2} \mathrm{Ph}\right), 37.67\left(\mathrm{CH}_{2} \mathrm{C}^{*}\right), 30.82\left(\mathrm{CH}_{\mathrm{i}}\right), 22.69$, $21.30\left(\mathrm{Me}_{\mathrm{i}}, \mathrm{Me}_{\mathrm{i}^{\prime}}\right), 17.54(\mathrm{Me})$.

$R_{\mathrm{Ru}}, R_{\mathrm{C}}$ diastereomer (20 \%). ${ }^{1} \mathrm{H} \mathrm{NMR}\left(500.13 \mathrm{MHz}, \mathrm{CD}_{2} \mathrm{Cl}_{2}, 298 \mathrm{~K}, \mathrm{ppm}\right): \delta 10.0-8.2$ (vbr, 1H, OH), 8.15 (brs, 1H, NH), 7.76 - 7.22 (m, 5H, $\mathrm{H}_{\mathrm{Ar}}$ ), 5.64, 5.48, 5.42, 5.01 (4 × d, $J=5.6 \mathrm{~Hz}, 4 \mathrm{H}, \mathrm{H}_{\mathrm{A}}, \mathrm{H}_{\mathrm{B}}, \mathrm{H}_{\mathrm{A}^{\prime}}, \mathrm{H}_{\mathrm{B}^{\prime}}$ ), 4.32 (AB system, $J_{\mathrm{AB}}=10.9 \mathrm{~Hz}, 2 \mathrm{H}, \mathrm{CH}_{2} \mathrm{Ph}$ ), 3.54 (m, 1H, C $\left.{ }^{*} \mathrm{H}\right), 2.72\left(\right.$ sept, $\left.J=6.8 \mathrm{~Hz}, 1 \mathrm{H}, \mathrm{H}_{\mathrm{i}}\right), 3.32\left(\mathrm{ABXX}\right.$ ' system, $J_{\mathrm{AB}}=13.6, J_{\mathrm{AX}}=$ 11.5, $J_{\mathrm{AX}}=10.2 \mathrm{~Hz}, 2 \mathrm{H}, \mathrm{CH}_{2} \mathrm{C}^{*}$ ), 2.03 (s, 3H, Me), 1.24 (d, $J=7.0 \mathrm{~Hz}, 3 \mathrm{H}, \mathrm{Me}_{\mathrm{i}}$ ), 1.21 (d, $\left.J=6.9 \mathrm{~Hz}, 3 \mathrm{H}, \mathrm{Me}_{\mathrm{i}^{\prime}}\right) .{ }^{13} C\left\{{ }^{1} \mathrm{H}\right\} \mathrm{NMR}\left(125.8 \mathrm{MHz}, \mathrm{CD}_{2} \mathrm{Cl}_{2}, 298 \mathrm{~K}, \mathrm{ppm}\right): \delta 170.24$ $(\mathrm{C}=\mathrm{O}), 133.95,130.61,129.00,128.84$ (6C, $\left.\mathrm{C}_{\mathrm{Ar}}\right), 108.31,100.81$ (2C, $\left.\mathrm{C}_{\text {p-cymene }}\right), 84.50$, 84.14, 84.01, 83.56 ( $\left.\mathrm{CH}_{\mathrm{A}}, \mathrm{CH}_{\mathrm{B}}, \mathrm{CH}_{\mathrm{A}^{\prime}}, \mathrm{CH}_{\mathrm{B}^{\prime}}\right), 59.38\left(\mathrm{C}^{*}\right), 39.22\left(\mathrm{CH}_{2} \mathrm{Ph}\right), 38.38\left(\mathrm{CH}_{2} \mathrm{C}^{*}\right)$, $30.63\left(\mathrm{CH}_{\mathrm{i}}\right), 21.83,21.79\left(\mathrm{Me}_{\mathrm{i}}, \mathrm{Me}_{\mathrm{i}^{\prime}}\right), 18.07(\mathrm{Me})$.

[( $\left.\left.\boldsymbol{\eta}^{5}-\mathrm{C}_{5} \mathbf{M e}_{5}\right) \operatorname{IrCl}\left(\boldsymbol{\kappa}^{2} \boldsymbol{N}, \boldsymbol{S}-\mathbf{H L}\right)\right] \mathbf{C l}(2 \mathrm{a})$. Yield: 85 \%. Diastereomeric ratio: 91/9. Anal. ${ }^{20}$ calcd for $\mathrm{C}_{21} \mathrm{H}_{30} \mathrm{Cl}_{2} \mathrm{IrNO}_{2} \mathrm{~S} \cdot \mathrm{H}_{2} \mathrm{O}$, \%: C, 39.3; H, 5.0; N, 2.2; S, 5.0. Found, \%: C, 39.1; H, 5.0; N, 2.2; S, 5.0. IR (solid, $\mathrm{cm}^{-1}$ ): v(OH) 2973 (vbr), v(C=O) 1715 (s). CD (acetone, $\left.5.1 \times 10^{-4} \mathrm{M}, 298 \mathrm{~K}\right): \lambda, \mathrm{nm},(\Delta \varepsilon): 335(+1.28)$.

$S_{\mathrm{Ir}}, R_{\mathrm{C}}$ diastereomer (91 \%). ${ }^{1} \mathrm{H} \mathrm{NMR}\left(500.13 \mathrm{MHz} \mathrm{CDCl}_{3}, 298 \mathrm{~K}, \mathrm{ppm}\right): \delta 7.55-7.33$ (2 × m, 5H, $\mathrm{H}_{\mathrm{Ar}}$ ), 6.20-5.30 (vbr, 1H, OH), 4.51 (AB system, $J=11.7 \mathrm{~Hz}, 2 \mathrm{H}, \mathrm{CH}_{2} \mathrm{Ph}$ ),

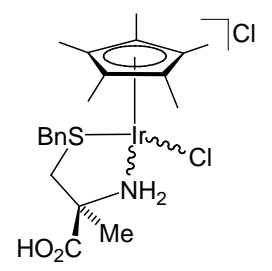
3.56 (AB system, $J=10.8 \mathrm{~Hz}, 2 \mathrm{H}, \mathrm{CH}_{2} \mathrm{C}^{*}$ ), 2.00 (brs, $3 \mathrm{H}, \mathrm{C}^{*} \mathrm{Me}$ ), 1.64 (s, 15H, $\left.\mathrm{C}_{5} \mathrm{Me}_{5}\right) \cdot{ }^{13} \mathrm{C}\left\{{ }^{1} \mathrm{H}\right\} \mathrm{NMR}\left(125.8 \mathrm{MHz}, \mathrm{CDCl}_{3}, 298 \mathrm{~K}, \mathrm{ppm}\right): \delta$ $169.82(\mathrm{C}=\mathrm{O}), 132.70,130.58,129.05,128.95\left(\mathrm{C}_{\mathrm{Ar}}\right), 91.87\left(\mathrm{C}_{5} \mathrm{Me}_{5}\right)$, $67.75\left(\mathrm{C}^{*}\right), 44.90\left(\mathrm{CH}_{2} \mathrm{Ph}\right), 38.71\left(\mathrm{CH}_{2} \mathrm{C}^{*}\right), 24.99\left(\mathrm{C}^{*} \mathrm{Me}\right), 8.84\left(\mathrm{C}_{5} \mathrm{Me}_{5}\right)$. 
$R_{\mathrm{Ir}}, R_{\mathrm{C}}$ diastereomer (9 \%). ${ }^{1} \mathrm{H}$ NMR (500.13 MHz, $\left.\mathrm{CDCl}_{3}, 298 \mathrm{~K}, \mathrm{ppm}\right): \delta 7.55-7.33$ (2 $\times$ m, 5H, $\mathrm{H}_{\mathrm{Ar}}$ ), 4.62 (AB system, $J=11.5 \mathrm{~Hz}, 2 \mathrm{H}, \mathrm{CH}_{2} \mathrm{Ph}$ ), 3.62 (AB system, $J=11.3$ $\mathrm{Hz}, 2 \mathrm{H}, \mathrm{CH}_{2} \mathrm{C}^{*}$ ), 1.93 (brs, 3H, C ${ }^{*} \mathrm{Me}$ ), 1.67 (s, 15H, $\left.\mathrm{C}_{5} \mathrm{Me}_{5}\right) \cdot{ }^{13} \mathrm{C}\left\{{ }^{1} \mathrm{H}\right\}$ NMR (125.8 $\left.\mathrm{MHz}, \mathrm{CDCl}_{3}, 298 \mathrm{~K}, \mathrm{ppm}\right):$ 130.63, 129.21, $129.00\left(\mathrm{C}_{\mathrm{Ar}}\right), 92.20\left(\mathrm{C}_{5} \mathrm{Me}_{5}\right), 67.64\left(\mathrm{C}^{*}\right)$, $45.23\left(\mathrm{CH}_{2} \mathrm{Ph}\right), 40.51\left(\mathrm{CH}_{2} \mathrm{C}^{*}\right), 25.50\left(\mathrm{C}^{*} \mathrm{Me}\right), 9.07\left(\mathrm{C}_{5} \mathrm{Me}_{5}\right)$.

[( $\left.\eta^{6}-\boldsymbol{p}-\mathrm{MeC}_{6} \mathrm{H}_{4} \mathbf{i P r}\right) \operatorname{RuCl}\left(\boldsymbol{\kappa}^{2} \boldsymbol{N}, \boldsymbol{S}\right.$-HL2)]Cl (2b). Yield: 70 \%. Isomeric ratio: 64/27/9. Anal. ${ }^{20}$ calcd for $\mathrm{C}_{21} \mathrm{H}_{29} \mathrm{Cl}_{2} \mathrm{NO}_{2} \mathrm{RuS} \cdot 3 \mathrm{H}_{2} \mathrm{O}$, \%: C, 43.1; H, 6.0; N, 2.4; S, 5.5. Found, \%: C, 43.4; H, 6.4; N, 2.3; S, 5.5. IR (solid, $\mathrm{cm}^{-1}$ ): v(OH) 2961 (vbr), v(C=O) 1729 (s). CD (acetone, $\left.5.5 \times 10^{-4} \mathrm{M}, 298 \mathrm{~K}\right): \lambda, \mathrm{nm},(\Delta \varepsilon): 362(+0.63)$.

Isomer A, 64 \%. ${ }^{1} \mathrm{H} N M R\left(500.13 \mathrm{MHz}, \mathrm{CD}_{3} \mathrm{OD}, 298 \mathrm{~K}, \mathrm{ppm}\right): \delta 7.58-7.40$ (m, 5H, $\left.\mathrm{H}_{\mathrm{Ar}}\right)$, 5.76, 5.40, 5.37, $4.46\left(4 \times \mathrm{d}, J=5.9 \mathrm{~Hz}, 4 \mathrm{H}, \mathrm{H}_{\mathrm{A}}, \mathrm{H}_{\mathrm{B}}, \mathrm{H}_{\mathrm{A}^{\prime}}, \mathrm{H}_{\mathrm{B}^{\prime}}\right), 4.30$ (AB system,

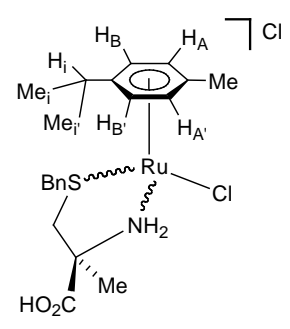
$\left.J_{\mathrm{AB}}=11.0 \mathrm{~Hz}, 2 \mathrm{H}, \mathrm{CH}_{2} \mathrm{Ph}\right), 3.16\left(\mathrm{AB}\right.$ system, $J_{\mathrm{AB}}=11.8 \mathrm{~Hz}, 2 \mathrm{H}$, $\mathrm{CH}_{2} \mathrm{C}^{*}$ ), 2.87 (sept, $J=6.9 \mathrm{~Hz} 1 \mathrm{H}, \mathrm{H}_{\mathrm{i}}$ ), 1.91 (s, 3H, Me), 1.67 (s, 3H, $\left.\mathrm{C}^{*} \mathrm{Me}\right), 1.30,1.28\left(2 \times\right.$ brs, $\left.6 \mathrm{H}, \mathrm{Me}_{\mathrm{i}}, \mathrm{Me}_{\mathrm{i}^{\prime}}\right) \cdot{ }^{13} \mathrm{C}\left\{{ }^{1} \mathrm{H}\right\}$ NMR (125.8 $\left.M H z, C D_{3} O D, 298 \mathrm{~K}, \mathrm{ppm}\right): \delta 173.86(\mathrm{C}=\mathrm{O}), 135.43,131.77,130.38$, $130.13\left(\mathrm{C}_{\mathrm{Ar}}\right), 112.46,99.90$ ( $\left.\mathrm{C}_{p-\text {-cymene }}\right), 87.78,84.96,84.29,83.10\left(\mathrm{CH}_{\mathrm{A}}, \mathrm{CH}_{\mathrm{B}}, \mathrm{CH}_{\mathrm{A}^{\prime}}\right.$, $\left.\mathrm{CH}_{\mathrm{B}^{\prime}}\right), 64.82\left(\mathrm{C}^{*}\right), 45.27\left(\mathrm{CH}_{2} \mathrm{C}^{*}\right), 39.78\left(\mathrm{CH}_{2} \mathrm{Ph}\right), 32.08\left(\mathrm{CH}_{\mathrm{i}}\right), 26.18\left(\mathrm{C}^{*} \mathrm{Me}\right)$, 23.67, $20.89\left(\mathrm{Me}_{\mathrm{i}}, \mathrm{Me}_{\mathrm{i}^{\prime}}\right), 18.84(\mathrm{Me})$.

Isomer B, $27 \% .{ }^{1} \mathrm{H} N M R\left(500.13 \mathrm{MHz}, \mathrm{CD}_{3} \mathrm{OD}, 298 \mathrm{~K}, \mathrm{ppm}\right): \delta 7.58-7.40(\mathrm{~m}, 5 \mathrm{H}$, $\left.\mathrm{H}_{\mathrm{Ar}}\right)$, 5.63, 5.34, 5.20, $4.56\left(4 \times \mathrm{d}, J=6.3 \mathrm{~Hz}, 4 \mathrm{H}, \mathrm{H}_{\mathrm{A}}, \mathrm{H}_{\mathrm{B}}, \mathrm{H}_{\mathrm{A}^{\prime}}, \mathrm{H}_{\mathrm{B}^{\prime}}\right), 4.34$ (AB system, $J_{\mathrm{AB}}=11.0 \mathrm{~Hz}, 2 \mathrm{H}, \mathrm{CH}_{2} \mathrm{Ph}$ ), $3.38\left(\mathrm{AB}\right.$ system, $\left.J_{\mathrm{AB}}=11.4 \mathrm{~Hz}, 2 \mathrm{H}, \mathrm{CH}_{2} \mathrm{C}^{*}\right), 2.79$ (sept, $J$ = 6.8 Hz, $\left.1 \mathrm{H}, \mathrm{H}_{\mathrm{i}}\right), 1.84(\mathrm{~s}, 3 \mathrm{H}, \mathrm{Me}), 1.44\left(\mathrm{~s}, 3 \mathrm{H}, \mathrm{C}^{*} \mathrm{Me}\right), 1.26,1.25\left(2 \times\right.$ brs, $6 \mathrm{H}, \mathrm{Me}_{\mathrm{i}}$, $\left.\mathrm{Me}_{\mathrm{i}^{\prime}}\right) .{ }^{13} C\left\{{ }^{1} \mathrm{H}\right\} \operatorname{NMR}\left(125.8 \mathrm{MHz}, C D_{3} \mathrm{OD}, 298 \mathrm{~K}, \mathrm{ppm}\right): \delta$ 134.84, 131.74, 130.33, $130.06\left(\mathrm{C}_{\mathrm{Ar}}\right), 113.34,98.68$ ( $\left.\mathrm{C}_{p-\text {-cymene }}\right)$, 85.89, 85.78, 85.39, $82.87\left(\mathrm{CH}_{\mathrm{A}}, \mathrm{CH}_{\mathrm{B}}, \mathrm{CH}_{\mathrm{A}^{\prime}}\right.$, 
$\left.\mathrm{CH}_{\mathrm{B}^{\prime}}\right), 65.53\left(\mathrm{C}^{*}\right), 44.35\left(\mathrm{CH}_{2} \mathrm{C}^{*}\right)$, $39.91\left(\mathrm{CH}_{2} \mathrm{Ph}\right), 32.51\left(\mathrm{CH}_{\mathrm{i}}\right)$, 23.39, $21.31\left(\mathrm{Me}_{\mathrm{i}}, \mathrm{Me}_{\mathrm{i}^{\prime}}\right)$, $17.61(\mathrm{Me})$.

Isomer C, $9 \%$. ${ }^{1} \mathrm{H} N \mathrm{NMR}\left(500.13 \mathrm{MHz}, \mathrm{CD}_{3} \mathrm{OD}, 298 \mathrm{~K}, \mathrm{ppm}\right): \delta 7.58-7.40$ (m, 5H, $\mathrm{H}_{\mathrm{Ar}}$ ), 4.02 (AB system, $J_{\mathrm{AB}}=11.9 \mathrm{~Hz}, 2 \mathrm{H}, \mathrm{CH}_{2} \mathrm{Ph}$ ), 2.66 (sept, $J=6.8 \mathrm{~Hz}, 1 \mathrm{H}, \mathrm{H}_{\mathrm{i}}$ ), 1.25, $1.24\left(2 \times\right.$ brs, $\left.6 \mathrm{H}, \mathrm{Me}_{\mathrm{i}}, \mathrm{Me}_{\mathrm{i}^{\prime}}\right) .{ }^{13} C\left\{{ }^{1} \mathrm{H}\right\} \mathrm{NMR}\left(125.8 \mathrm{MHz}, \mathrm{CD}_{3} \mathrm{OD}, 298 \mathrm{~K}, \mathrm{ppm}\right): \delta$ 136.21, 131.80, 131.51, $130.21\left(\mathrm{C}_{\mathrm{Ar}}\right), 100.97$ ( $\left.\mathrm{C}_{p \text {-cymene }}\right), 85.87,84.80,84.08,823.10$ $\left(\mathrm{CH}_{\mathrm{A}}, \mathrm{CH}_{\mathrm{B}}, \mathrm{CH}_{\mathrm{A}^{\prime}}, \mathrm{CH}_{\mathrm{B}^{\prime}}\right), 42.61\left(\mathrm{CH}_{2} \mathrm{Ph}\right), 39.91\left(\mathrm{CH}_{2} \mathrm{C}^{*}\right), 32.01\left(\mathrm{CH}_{\mathrm{i}}\right), 22.98,22.34$ $\left(\mathrm{Me}_{\mathrm{i}}, \mathrm{Me}_{\mathrm{i}}{ }^{\prime}\right), 18.22(\mathrm{Me})$.

Preparation of the complexes $\left[\left(\eta^{5}-\mathrm{C}_{5} \mathrm{Me}_{5}\right) \operatorname{IrCl}\left(\kappa^{2} N, O-\mathrm{L}\right)\right](\mathrm{L}=\mathrm{L} 1$ (3a), L2 (4a), L3 (5a)), [( $\left.\left.\eta^{5}-\mathrm{C}_{5} \mathrm{Me}_{5}\right) \operatorname{Ir}\left(\kappa^{3} N, O, S-\mathrm{L}\right)\right] \mathrm{Cl}(\mathrm{L}=\mathrm{L} 1(6 \mathrm{aCl}), \mathrm{L} 2(7 \mathrm{aCl}))$ and $\left[\left(\eta^{6}-p\right.\right.$ $\left.\left.\mathrm{MeC}_{6} \mathrm{H}_{4} i \mathrm{Pr}\right) \operatorname{RuCl}\left(\kappa^{2} N, O-\mathrm{L}\right)\right], \quad(\mathrm{L}=\mathrm{L} 1 \quad(3 \mathrm{~b}), \quad \mathrm{L} 2 \quad(4 \mathrm{~b}), \quad \mathrm{L} 3 \quad(5 \mathrm{~b})) \quad\left[\left(\eta^{6}-p-\right.\right.$ $\left.\left.\mathrm{MeC}_{6} \mathrm{H}_{4} i \mathrm{Pr}\right) \operatorname{RuCl}\left(\kappa^{3} N, O, S-\mathrm{L}\right)\right] \mathrm{Cl}(\mathrm{L}=\mathrm{L1}(6 \mathrm{bCl}), \mathrm{L} 2$ (7bCl)). At room temperature, to a suspension of the corresponding dimer $\left[\left\{\left(\eta^{\mathrm{n}} \text {-ring }\right) \mathrm{MCl}\right\}_{2}(\mu-\mathrm{Cl})_{2}\right](0,32 \mathrm{mmol})$, in 10 $\mathrm{mL}$ of $\mathrm{MeOH}, 0.64 \mathrm{mmol}$ of the corresponding cysteine-derived ligand, HL1 or HL2, were added. The resulting yellow (Ir) or orange (Ru) solution was stirred for 15 min and then $64.7 \mathrm{mg}(0.77 \mathrm{mmol})$ of $\mathrm{NaHCO}_{3}$ were added. The suspension was vigorously stirred for $2 \mathrm{~h}$ and then concentrated in vacuum until dryness. The residue was extracted with $\mathrm{CH}_{2} \mathrm{Cl}_{2}(4 \times 5 \mathrm{~mL})$ and the resulting solution was concentrated under reduced pressure to $c a$. $3 \mathrm{~mL}$. The slow addition of $n$-hexane led to the precipitation of a yellow solid which was washed with $n$-hexane $(4 \times 5 \mathrm{~mL})$ and vacuum-dried. The solid was spectroscopically characterized as a mixture of 3 and 6 CI (HL1) or 4 and 7CI (HL2) compounds. With the ligand HL3, pure complexes 5 were obtained. Yield: $\mathbf{3 a}+\mathbf{6 a C l}$, $74 \%$; 3b + 6bCl, 74\%; 4a + 7aCl, $56 \%$; 7bCl, $65 \%$. 
3a + 6aCl, Anal. ${ }^{20}$ calcd for $\mathrm{C}_{20} \mathrm{H}_{27} \mathrm{ClIrNO}_{2} \mathrm{~S} \cdot 2 \mathrm{H}_{2} \mathrm{O}, \%$ : C, 39.4; H, 5.1; N, 2.3; S, 5.3. Found, \%: C, 39.5; H, 5.3; N 2.5; S 5.6. IR (solid, $\mathrm{cm}^{-1}$ ): v(C=O) 1611(s). CD (acetone, $\left.3.8 \times 10^{-4} \mathrm{M}, 298 \mathrm{~K}\right): \lambda, \mathrm{nm},(\Delta \varepsilon): 344(+2.81)$.

3b + 6bCl, Anal. ${ }^{20}$ calcd for $\mathrm{C}_{20} \mathrm{H}_{26} \mathrm{ClNO}_{2} \mathrm{RuS} \cdot 2 \mathrm{H}_{2} \mathrm{O}, \%$ : C, 46.4; H, 5.8; N, 2.7; S, 6.2. Found, \%: C, 46.8; H, 5.8; N, 2.9; S, 6.5. IR (solid, $\mathrm{cm}^{-1}$ ): v(C=O) 1653 (s). CD (acetone, $\left.5.0 \times 10^{-4} \mathrm{M}, 298 \mathrm{~K}\right): \lambda, \mathrm{nm},(\Delta \varepsilon): 334(-0.60)$.

4a + 7aCl, Anal. ${ }^{20}$ calcd for $\mathrm{C}_{21} \mathrm{H}_{29} \mathrm{ClIrNO}_{2} \mathrm{~S} \cdot 3 \mathrm{H}_{2} \mathrm{O}, \%$ : C, 39.3; H, 5.4; N, 2.2; S, 5.0. Found, \%: C, 39.1; H, 5.2; N, 2.2; S, 4.6. IR (solid, $\mathrm{cm}^{-1}$ ): $v(\mathrm{C}=\mathrm{O}) 1653$ (s).

7bCl, Anal. ${ }^{20}$ calcd for $\mathrm{C}_{21} \mathrm{H}_{28} \mathrm{ClNO}_{2} \mathrm{RuS} \cdot 3 \mathrm{H}_{2} \mathrm{O}$, \%: C, 45.9; H, 6.2; N, 2.6; S, 5.8 . Found, \%: C, 45.6; H, 5.8; N, 2.7; S, 5.8. IR (solid, $\mathrm{cm}^{-1}$ ): v(C=O) 1642 (s). CD (acetone, $\left.5.1 \times 10^{-4} \mathrm{M}, 298 \mathrm{~K}\right): \lambda, \mathrm{nm},(\Delta \varepsilon): 332(-1.34)$.

[( $\left.\left.\eta^{5}-\mathrm{C}_{5} \mathbf{M e}_{5}\right) \operatorname{IrCl}\left(\boldsymbol{k}^{2} \boldsymbol{N}, \boldsymbol{O}-\mathbf{L} 1\right)\right]$ (3a). Yield: $67 \%$. Isomeric ratio: 90/10.

$S_{\mathrm{Ir}}, R_{\mathrm{C}}$ diastereomer (90 \%). ${ }^{1} \mathrm{H} \mathrm{NMR}\left(300.13 \mathrm{MHz}, \mathrm{CDCl}_{3}, 298 \mathrm{~K}, \mathrm{ppm}\right): \delta 7.70-7.12$

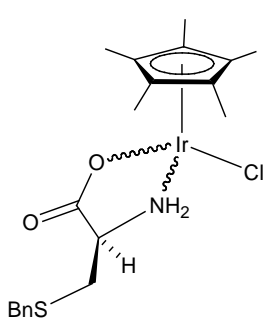
$\left(2 \times \mathrm{m}, 5 \mathrm{H}, \mathrm{H}_{\mathrm{Ar}}\right), 6.35(\mathrm{br}, 1 \mathrm{H}, \mathrm{NH}), 4.66\left(\mathrm{AB}\right.$ system, $J_{\mathrm{AB}}=11.2 \mathrm{~Hz}$, 2H, $\mathrm{CH}_{2} \mathrm{Ph}$ ), 4.45 (br, 1H, NH), 3.87 (brs, $\left.1 \mathrm{H}, \mathrm{C}^{*} \mathrm{H}\right), 3.59,2.82(2 \times$ br, $2 \mathrm{H}, \mathrm{CH}_{2} \mathrm{C}^{*}$ ), 1.60 (brs, $\left.15 \mathrm{H}, \mathrm{C}_{5} \mathrm{Me}_{5}\right) .{ }^{13} \mathrm{C}\left\{{ }^{1} \mathrm{H}\right\} \mathrm{NMR}(125.8 \mathrm{MHz}$, $\left.\mathrm{CDCl}_{3}, 298 \mathrm{~K}, \mathrm{ppm}\right): \delta 179.48(\mathrm{C}=\mathrm{O}), 133.58,130.77,128.69,128.42$ $\left(\mathrm{C}_{\mathrm{Ar}}\right), 90.99\left(\mathrm{C}_{5} \mathrm{Me}_{5}\right), 61.40\left(\mathrm{C}^{*}\right), 40.66\left(\mathrm{CH}_{2} \mathrm{C}^{*}\right), 37.40\left(\mathrm{CH}_{2} \mathrm{Ph}\right), 8.45\left(\mathrm{C}_{5} \mathrm{Me}_{5}\right)$.

$R_{\mathrm{II}}, R_{\mathrm{C}}$ diastereomer (10 \%). ${ }^{1} \mathrm{H}$ NMR (300.13 MHz, $\left.\mathrm{CDCl}_{3}, 298 \mathrm{~K}, \mathrm{ppm}\right): \delta 3.92$ (d, $J=$ $\left.12.8 \mathrm{~Hz}, 1 \mathrm{H}, \mathrm{CH}_{2} \mathrm{Ph}\right), 3.87\left(1 \mathrm{H}, \mathrm{C}^{*} \mathrm{H}\right), 3.70\left(1 \mathrm{H}, \mathrm{CH}_{2} \mathrm{Ph}\right), 3.54\left(1 \mathrm{H}, \mathrm{CH}_{2} \mathrm{C}^{*}\right), 2.55$ (pt, $J$ $\left.=12.3 \mathrm{~Hz}, 1 \mathrm{H}, \mathrm{CH}_{2} \mathrm{C}^{*}\right), 1.67$ (brs, $\left.15 \mathrm{H}, \mathrm{C}_{5} \mathrm{Me}_{5}\right) .{ }^{13} \mathrm{C}\left\{{ }^{1} \mathrm{H}\right\} \mathrm{NMR}\left(125.8 \mathrm{MHz}, \mathrm{CDCl}_{3}, 298\right.$ K, ppm): $\delta 91.04\left(\mathrm{C}_{5} \mathrm{Me}_{5}\right), 61.40\left(\mathrm{C}^{*}\right), 41.05\left(\mathrm{CH}_{2} \mathrm{C}^{*}\right), 39.40\left(\mathrm{CH}_{2} \mathrm{Ph}\right), 8.80\left(\mathrm{C}_{5} \mathrm{Me}_{5}\right)$.

$\left[\left(\eta^{5}-\mathrm{C}_{5} \mathrm{Me}_{5}\right) \operatorname{Ir}\left(\boldsymbol{\kappa}^{3} N, O, S-\mathrm{L1}\right)\right] \mathrm{Cl}(\mathbf{6 a C l})$. Yield: $7 \%$. 
$R_{\mathrm{Ir}}, R_{\mathrm{C}}$ diastereomer. ${ }^{1} \mathrm{H}$ NMR (300.13 $\left.\mathrm{MHz}, \mathrm{CDCl}_{3}, 298 \mathrm{~K}, \mathrm{ppm}\right): \delta 4.42$ (brd, $J=12.4 \mathrm{~Hz}, 1 \mathrm{H}, \mathrm{CH}_{2} \mathrm{Ph}$ ), 4.29 (brs, $1 \mathrm{H}, \mathrm{C}^{*} \mathrm{H}$ ), 4.06 (brd, $J=12.4$ $\left.\mathrm{Hz}, 1 \mathrm{H}, \mathrm{CH}_{2} \mathrm{Ph}\right), 3.54\left(1 \mathrm{H}, \mathrm{CH}_{2} \mathrm{C}^{*}\right), 2.32\left(\mathrm{~d}, J=13.3 \mathrm{~Hz}, 1 \mathrm{H}, \mathrm{CH}_{2} \mathrm{C}^{*}\right.$ ), 1.87 (brs, 15H, C $\left.{ }_{5} \mathrm{Me}_{5}\right) \cdot{ }^{13} \mathrm{C}\left\{{ }^{1} \mathrm{H}\right\} \mathrm{NMR}\left(125.8 \mathrm{MHz}, \mathrm{CDCl}_{3}, 298 \mathrm{~K}\right.$, ppm): $\delta 89.04\left(C_{5} \mathrm{Me}_{5}\right), 60.69\left(\mathrm{C}^{*}\right), 38.26\left(\mathrm{CH}_{2} \mathrm{Ph}\right), 32.24\left(\mathrm{CH}_{2} \mathrm{C}^{*}\right), 9.25\left(\mathrm{C}_{5} \mathrm{Me}_{5}\right)$.

$\left[\left(\eta^{6}-p-\mathrm{MeC}_{6} \mathrm{H}_{4} \mathrm{iPr}\right) \mathrm{RuCl}\left(k^{2} N, O-\mathrm{L} 1\right)\right](3 \mathrm{~b})$. Yield: $3 \%$

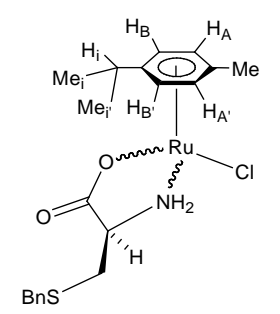

${ }^{1} \mathrm{H} \mathrm{NMR}\left(500.13 \mathrm{MHz}, \mathrm{CDCl}_{3}, 250 \mathrm{~K}, \mathrm{ppm}\right): \delta$ 5.05, $4.57(2 \times$ brs, $2 \mathrm{H}$, $\left.\mathrm{CH}_{2} \mathrm{C}^{*}\right), 4.31,3.85\left(2 \times\right.$ brs, $\left.2 \mathrm{H}, \mathrm{CH}_{2} \mathrm{Ph}\right), 1.85$ (s, 3H, Me). ${ }^{13} C\left\{{ }^{1} H\right\}$ NMR (125.8 MHz, $\left.\mathrm{CDCl}_{3}, 250 \mathrm{~K}, \mathrm{ppm}\right): \delta 45.60\left(\mathrm{CH}_{2} \mathrm{C}^{*}\right), 38.08$ $\left(\mathrm{CH}_{2} \mathrm{Ph}\right), 17.91(\mathrm{Me})$.

[( $\left.\left.\eta^{6}-\boldsymbol{p}-\mathrm{MeC}_{6} \mathbf{H}_{4} \mathbf{i P r}\right) \mathbf{R u}\left(\boldsymbol{\kappa}^{3} \boldsymbol{N}, \boldsymbol{O}, \boldsymbol{S}-\mathrm{L1}\right)\right] \mathrm{Cl}(\mathbf{6 b C l})$. Yield: 71 \%. Isomeric ratio: 96/4.

$R_{\mathrm{Ru}}, R_{\mathrm{C}}, S_{\mathrm{S}}$ diastereomer (96 \%). ${ }^{1} \mathrm{H} \mathrm{NMR}\left(500.13 \mathrm{MHz}, \mathrm{CDCl}_{3}, 250 \mathrm{~K}, \mathrm{ppm}\right): \delta 7.55$ 7.35 (m, 5H, $\mathrm{H}_{\mathrm{Ar}}$ ), 6.83 (br, 1H, NH), 6.73 (br, 1H, NH), 5.50, 5.38, 5.33, $4.98(4 \times \mathrm{s}$, 4H, $\mathrm{H}_{\mathrm{A}}, \mathrm{H}_{\mathrm{B}}, \mathrm{H}_{\mathrm{A}^{\prime}}, \mathrm{H}_{\mathrm{B}^{\prime}}$ ), 3.96 ( $\mathrm{AB}$ system, $J_{\mathrm{AB}}=11.1 \mathrm{~Hz}, 2 \mathrm{H}, \mathrm{CH}_{2} \mathrm{Ph}$ ), 3.93 (brs, $1 \mathrm{H}$,

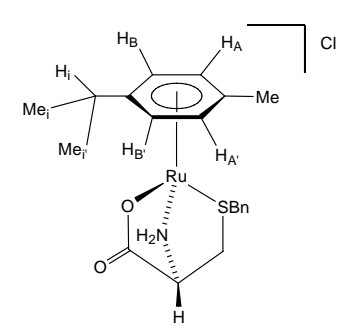
$\mathrm{C}^{*} \mathrm{H}$ ), $3.36\left(\mathrm{AB}\right.$ system, $J_{\mathrm{AB}}=13.1 \mathrm{~Hz}, 2 \mathrm{H}, \mathrm{CH}_{2} \mathrm{C}^{*}$ ), 2.70 (br, $1 \mathrm{H}$, $\mathrm{H}_{\mathrm{i}}$ ), 2.11 (s, 3H, Me), 1.25, $1.23\left(2 \times \mathrm{d}, J=7.2 \mathrm{~Hz}, 6 \mathrm{H}, \mathrm{Me}_{\mathrm{i}}, \mathrm{Me}_{\mathrm{i}^{\prime}}\right.$ ). ${ }^{13} \mathrm{C}\left\{{ }^{1} \mathrm{H}\right\} \mathrm{NMR}\left(125.8 \mathrm{MHz}, \mathrm{CDCl}_{3}, 250 \mathrm{~K}, \mathrm{ppm}\right): \delta 178.45(\mathrm{C}=\mathrm{O})$, 133.64, 130.46, 129.36, $129.15\left(\mathrm{C}_{\text {Ar }}\right), 107.37,96.99$ ( $\left.\mathrm{C}_{p \text {-cymene }}\right)$, 84.72, 83.27, 82.86, $81.57\left(\mathrm{CH}_{\mathrm{A}}, \mathrm{CH}_{\mathrm{B}}, \mathrm{CH}_{\mathrm{A}^{\prime}}, \mathrm{CH}_{\mathrm{B}^{\prime}}\right), 58.89\left(\mathrm{C}^{*}\right), 41.04\left(\mathrm{CH}_{2} \mathrm{Ph}\right), 32.80$ $\left(\mathrm{CH}_{2} \mathrm{C}^{*}\right), 31.26\left(\mathrm{CH}_{\mathrm{i}}\right), 22.61,22.42\left(\mathrm{Me}_{\mathrm{i}}, \mathrm{Me}^{\prime}\right), 18.44(\mathrm{Me})$.

$R_{\mathrm{Ru}}, R_{\mathrm{C}}, R_{\mathrm{S}}$ diastereomer (4 \%). ${ }^{1} \mathrm{H} N \mathrm{NMR}\left(500.13 \mathrm{MHz}, \mathrm{CDCl}_{3}, 250 \mathrm{~K}, \mathrm{ppm}\right): \delta 4.29,3.43$ ( $2 \times$ brs, $\left.2 \mathrm{H}, \mathrm{CH}_{2} \mathrm{Ph}\right), 3.05,2.49\left(2 \times\right.$ brs, $\left.2 \mathrm{H}, \mathrm{CH}_{2} \mathrm{C}^{*}\right), 1.99$ (s, 3H, Me). ${ }^{13} \mathrm{C}\left\{{ }^{1} \mathrm{H}\right\} N M R$ (125.8 MHz, $\left.\mathrm{CDCl}_{3}, 250 \mathrm{~K}, \mathrm{ppm}\right): \delta 38.71\left(\mathrm{CH}_{2} \mathrm{Ph}\right), 31.82\left(\mathrm{CH}_{2} \mathrm{C}^{*}\right), 18.44(\mathrm{Me})$.

[( $\left.\left.\boldsymbol{\eta}^{5}-\mathrm{C}_{5} \mathbf{M e}_{5}\right) \operatorname{IrCl}\left(\boldsymbol{k}^{2} \boldsymbol{N}, \boldsymbol{O}-\mathbf{L} 2\right)\right]$ (4a). Yield: 30\%. Isomeric ratio: 89/11. 
$S_{\mathrm{Ir}}, R_{\mathrm{C}}$ diastereomer (89 \%). ${ }^{1} \mathrm{H} \mathrm{NMR}\left(300.13 \mathrm{MHz}, \mathrm{CDCl}_{3}, 298 \mathrm{~K}, \mathrm{ppm}\right): \delta 7.65$ (br, $1 \mathrm{H}$,

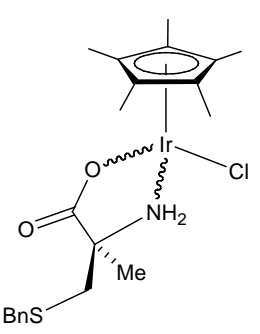
$\mathrm{NH}), 7.40-7.29\left(\mathrm{~m}, 5 \mathrm{H}, \mathrm{H}_{\mathrm{Ar}}\right.$ ), 5.71 (br, 1H, NH), 4.51 (AB system, $\left.J_{\mathrm{AB}}=12.1 \mathrm{~Hz}, 2 \mathrm{H}, \mathrm{CH}_{2} \mathrm{Ph}\right), 3.90\left(\mathrm{AB}\right.$ system, $J_{\mathrm{AB}}=10.8 \mathrm{~Hz}, 2 \mathrm{H}$, $\mathrm{CH}_{2} \mathrm{C}^{*}$ ), 1.78 (s, 3H, C ${ }^{*} \mathrm{Me}$ ), 1.55 (s, $\left.15 \mathrm{H}, \mathrm{C}_{5} \mathrm{Me}_{5}\right) .{ }^{13} \mathrm{C}\left\{{ }^{1} \mathrm{H}\right\} N M R$ (75.47 MHz, $\left.\mathrm{CDCl}_{3}, 298 \mathrm{~K}, \mathrm{ppm}\right): \delta 170.98(\mathrm{C}=\mathrm{O}), 133.24,130.76$, 128.83, $128.68\left(\mathrm{C}_{\mathrm{Ar}}\right), 91.17\left(\mathrm{C}_{5} \mathrm{Me}_{5}\right), 68.26\left(\mathrm{C}^{*}\right), 45.89\left(\mathrm{CH}_{2} \mathrm{C}^{*}\right), 38.87\left(\mathrm{CH}_{2} \mathrm{Ph}\right), 26.34$ $\left(\mathrm{C}^{*} \mathrm{Me}\right), 8.26\left(\mathrm{C}_{5} M e_{5}\right)$.

$R_{\mathrm{Ir}}, R_{\mathrm{C}}$ diastereomer (11\%). ${ }^{1} \mathrm{H} \mathrm{NMR}\left(300.13 \mathrm{MHz}, \mathrm{CDCl}_{3}, 298 \mathrm{~K}, \mathrm{ppm}\right): \delta 6.47$ (br, $1 \mathrm{H}$, NH), 5.87 (br, 1H, NH), 4.65 (d, $J=11.3 \mathrm{~Hz}, 1 \mathrm{H}, \mathrm{CH}_{2} \mathrm{Ph}$ ), 4.08 (d, $J=11.3 \mathrm{~Hz}, 1 \mathrm{H}$, $\left.\mathrm{CH}_{2} \mathrm{Ph}\right), 3.48\left(1 \mathrm{H}, \mathrm{CH}_{2} \mathrm{C}^{*}\right), 2.42\left(\mathrm{~d}, J=10.6 \mathrm{~Hz}, 1 \mathrm{H}, \mathrm{CH}_{2} \mathrm{C}^{*}\right), 1.58$ (s, $\left.15 \mathrm{H}, \mathrm{C}_{5} \mathrm{Me}_{5}\right)$. ${ }^{13} C\left\{{ }^{1} \mathrm{H}\right\}$ NMR (75.47 MHz, $\left.C D C l_{3}, 298 \mathrm{~K}, \mathrm{ppm}\right): \delta 91.50\left(\mathrm{C}_{5} \mathrm{Me}_{5}\right), 68.07\left(\mathrm{C}^{*}\right), 46.22$ $\left(\mathrm{CH}_{2} \mathrm{C}^{*}\right), 40.62\left(\mathrm{CH}_{2} \mathrm{Ph}\right), 8.49\left(\mathrm{C}_{5} \mathrm{Me}_{5}\right)$.

$\left[\left(\eta^{5}-\mathrm{C}_{5} \mathrm{Me}_{5}\right) \operatorname{Ir}\left(\boldsymbol{\kappa}^{3} N, O, S-\mathrm{L} 2\right)\right] \mathrm{Cl}(7 \mathrm{aCl})$. Yield: $26 \%$

$R_{\mathrm{II}}, R_{\mathrm{C}}$ diastereomer. ${ }^{1} \mathrm{H} \mathrm{NMR}\left(300.13 \mathrm{MHz}, \mathrm{CDCl}_{3}, 298 \mathrm{~K}, \mathrm{ppm}\right): \delta 7.49-7.41$ (m, 5H,

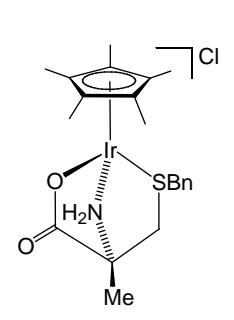
$\mathrm{H}_{\mathrm{Ar}}$ ), 6.36 (br, $\left.1 \mathrm{H}, \mathrm{NH}\right), 3.93\left(\mathrm{AB}\right.$ system, $J_{\mathrm{AB}}=11.9 \mathrm{~Hz}, 2 \mathrm{H}, \mathrm{CH}_{2} \mathrm{Ph}$ ), 3.65 (br, 1H, NH), 3.49 (brd, $J=13.6 \mathrm{~Hz}, 1 \mathrm{H}, \mathrm{CH}_{2} \mathrm{C}^{*}$ ), 2.17 (brd, $J=$ $13.6 \mathrm{~Hz}, 1 \mathrm{H}, \mathrm{CH}_{2} \mathrm{C}^{*}$ ), 1.88 (s, 15H, $\mathrm{C}_{5} \mathrm{Me}_{5}$ ), 1.75 (s, 3H, C* Me). ${ }^{13} \mathrm{C}\left\{{ }^{1} \mathrm{H}\right\} \mathrm{NMR}\left(75.47 \mathrm{MHz}, \mathrm{CDCl}_{3}, 298 \mathrm{~K}, \mathrm{ppm}\right): \delta 180.38(\mathrm{C}=\mathrm{O})$, 132.37, 130.30, 129.17, $128.89\left(\mathrm{C}_{\mathrm{Ar}}\right), 89.05\left(\mathrm{C}_{5} \mathrm{Me}_{5}\right), 66.39\left(\mathrm{C}^{*}\right), 39.31\left(\mathrm{CH}_{2} \mathrm{Ph}\right), 36.47$ $\left(\mathrm{CH}_{2} \mathrm{C}^{*}\right), 22.50\left(\mathrm{C}^{*} \mathrm{Me}\right), 9.34\left(\mathrm{C}_{5} \mathrm{Me}_{5}\right)$.

[( $\left.\left.\eta^{6}-p-\mathrm{MeC}_{6} \mathrm{H}_{4} \mathbf{i P r}\right) \mathbf{R u}\left(\boldsymbol{\kappa}^{3} \boldsymbol{N}, \boldsymbol{O}, \mathbf{S}-\mathbf{L} 2\right)\right] \mathrm{Cl}(\mathbf{7 b C l})$. Yield: 65 \%. Isomeric ratio: 96/4.

$R_{\mathrm{Ru}}, R_{\mathrm{C}}, S_{\mathrm{S}}$ diastereomer (96 \%). ${ }^{1} \mathrm{H} N M R\left(400.16 \mathrm{MHz}, \mathrm{CDCl}_{3}, 298 \mathrm{~K}, \mathrm{ppm}\right): \delta 7.62$ (br, 1H, NH), $7.44-7.26\left(\mathrm{~m}, 5 \mathrm{H}, \mathrm{H}_{\mathrm{Ar}}\right), 6.63$ (br, 1H, NH), 5.51, 5.30, 5.17 (3 × d, $J=4.2$ $\mathrm{Hz}, 4 \mathrm{H}, \mathrm{H}_{\mathrm{A}}, \mathrm{H}_{\mathrm{B}}, \mathrm{H}_{\mathrm{A}^{\prime}}, \mathrm{H}_{\mathrm{B}^{\prime}}$ ), $3.82\left(\mathrm{AB}\right.$ system, $\left.J_{\mathrm{AB}}=11.4 \mathrm{~Hz}, 2 \mathrm{H}, \mathrm{CH}_{2} \mathrm{Ph}\right), 3.22(\mathrm{~d}, J=$ 


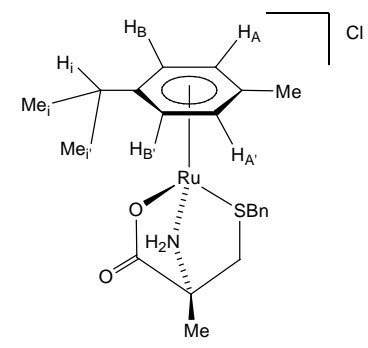

$\left.13.6 \mathrm{~Hz}, 2 \mathrm{H}, \mathrm{CH}_{2} \mathrm{C}^{*}\right), 2.71$ (m, 1H, $\mathrm{H}_{\mathrm{i}}$ ), 2.10 (s, 3H, Me), 1.61 (s, 3H, C $\left.{ }^{*} M e\right), 1.23,1.16\left(2 \times \mathrm{d}, J=7.1 \mathrm{~Hz}, 6 \mathrm{H}, \mathrm{Me}_{\mathrm{i}}, \mathrm{Me}_{\mathrm{i}}{ }^{\prime}\right)$. $\left.{ }^{13} \mathrm{C}_{\{1}^{1} \mathrm{H}\right\}$ NMR $\left(100.6 \mathrm{MHz}, \mathrm{CDCl}_{3}, 298 \mathrm{~K}, \mathrm{ppm}\right): \delta 178.67$ $(\mathrm{C}=\mathrm{O}), 133.67,130.43,129.14,129.01\left(\mathrm{C}_{\mathrm{Ar}}\right), 107.22,97.48\left(\mathrm{C}_{p-}\right.$ cymene), 84.87, 83.17, $81.60\left(\mathrm{CH}_{\mathrm{A}}, \mathrm{CH}_{\mathrm{B}}, \mathrm{CH}_{\mathrm{A}^{\prime}}, \mathrm{CH}_{\mathrm{B}^{\prime}}\right), 64.24\left(\mathrm{C}^{*}\right), 41.02\left(\mathrm{CH}_{2} \mathrm{Ph}\right), 37.70$ $\left.\left(\mathrm{CH}_{2} \mathrm{C}^{*}\right), 31.14\left(\mathrm{CH}_{\mathrm{i}}\right), 23.07\left(\mathrm{C}^{*} \mathrm{Me}\right), 22.55,22.47\left(\mathrm{Me}_{\mathrm{i}}, \mathrm{Me}_{\mathrm{i}}\right)^{\prime}\right), 18.14(\mathrm{Me})$.

$R_{\mathrm{Ru}}, R_{\mathrm{C}}, R_{\mathrm{S}}$ diastereomer (4 \%). ${ }^{1} \mathrm{H} N \mathrm{NR}$ (400.16 MHz, $\left.\mathrm{CDCl}_{3}, 298 \mathrm{~K}, \mathrm{ppm}\right): \delta$ 4.51, 2.97 $\left(2 \times\right.$ brs, $\left.2 \mathrm{H}, \mathrm{CH}_{2} \mathrm{Ph}\right), 2.97,2.27\left(2 \times\right.$ brs, $\left.\left.2 \mathrm{H}, \mathrm{CH}_{2} \mathrm{C}^{*}\right) .{ }^{13} \mathrm{C}^{1}{ }^{1} \mathrm{H}\right\} \mathrm{NMR}(100.6 \mathrm{MHz}$, $C D C l=298 \mathrm{~K}, \mathrm{ppm}): \delta 41.58\left(\mathrm{CH}_{2} \mathrm{Ph}\right), 36.75\left(\mathrm{CH}_{2} \mathrm{C}^{*}\right)$.

[( $\left.\left.\eta^{5}-\mathbf{C}_{5} \mathbf{M e}_{5}\right) \operatorname{IrCl}\left(\boldsymbol{c}^{2} \mathbf{O}, \mathbf{S}-\mathbf{L} 3\right)\right]$ (5a). Yield: $57 \%$. Diastereomeric ratio: 62/21/9/8. Anal. ${ }^{20}$ calcd for $\mathrm{C}_{25} \mathrm{H}_{35} \mathrm{ClIrNO}_{4} \mathrm{~S} \cdot 3 \mathrm{H}_{2} \mathrm{O}$, \%: C, 41.2; H, 5.6; N, 1.9; S, 4.4. Found, \%: C, 40.7; H, 5.2; N, 2.1; S, 4.8. IR (solid, $\left.\mathrm{cm}^{-1}\right): v\left(\mathrm{C}=\mathrm{O}_{\text {Вос }}\right) 1752$ (s), $v(\mathrm{C}=\mathrm{O}) 1630$ (s).

Isomer A, $62 \% .{ }^{1} H$ NMR (500.13 MHz, $\left.\mathrm{CDCl}_{3}, 298 \mathrm{~K}, \mathrm{ppm}\right): \delta 7.62$ - 7.56, $7.41-7.29$ $\left(2 \times \mathrm{m}, 5 \mathrm{H}, \mathrm{H}_{\mathrm{Ar}}\right), 6.15$ (br, $\left.1 \mathrm{H}, \mathrm{NH}\right), 5.05\left(\mathrm{AB}\right.$ system, $\left.J_{\mathrm{AB}}=12.2 \mathrm{~Hz}, 2 \mathrm{H}, \mathrm{CH}_{2} \mathrm{Ph}\right), 4.66$

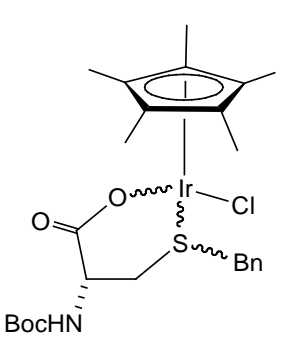
(br, $1 \mathrm{H}, \mathrm{C}^{*} \mathrm{H}$ ), 3.48 (dd, $J=11.8,1.6 \mathrm{~Hz}, 1 \mathrm{H}, \mathrm{CH}_{2} \mathrm{C}^{*}$ ), 2.43 (dd, $J=$ 11.8, $11.5 \mathrm{~Hz}, 1 \mathrm{H}, \mathrm{CH}_{2} \mathrm{C}^{*}$ ), 1.45 (brs, 9H, $\mathrm{Me}_{t \mathrm{Bu}}$ ), 1.43 (s, $15 \mathrm{H}$, $\left.\mathrm{C}_{5} \mathrm{Me}_{5}\right) .{ }^{13} C\left\{{ }^{1} \mathrm{H}\right\} N \mathrm{NMR}\left(125.8 \mathrm{MHz}, \mathrm{CDCl}_{3}, 298 \mathrm{~K}, \mathrm{ppm}\right): \delta 175.01$ $(\mathrm{C}=\mathrm{O}), 155.15\left(\mathrm{C}=\mathrm{O}_{\mathrm{Boc}}\right), 133.96,131.13,128.59,128.19\left(\mathrm{C}_{\mathrm{Ar}}\right)$, $89.94\left(C_{5} \mathrm{Me}_{5}\right), 79.26\left(\mathrm{C}_{t \mathrm{Bu}}\right), 50.01\left(\mathrm{C}^{*}\right), 37.44\left(\mathrm{CH}_{2} \mathrm{Ph}\right), 34.67\left(\mathrm{CH}_{2} \mathrm{C}^{*}\right), 28.44\left(\mathrm{Me}_{t \mathrm{Bu}}\right)$, $8.16\left(\mathrm{C}_{5} \mathrm{Me}_{5}\right)$.

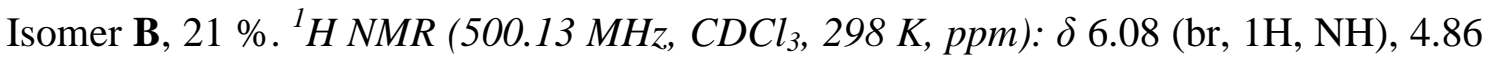
(d, $J=11.4 \mathrm{~Hz}, 1 \mathrm{H}, \mathrm{CH}_{2} \mathrm{Ph}$ ), 3.84 (d, $J=11.4 \mathrm{~Hz}, 1 \mathrm{H}, \mathrm{CH}_{2} \mathrm{Ph}$ ), 3.67 (br, $1 \mathrm{H}, \mathrm{C}^{*} \mathrm{H}$ ), 2.99 (dd, $J=9.9,4.0 \mathrm{~Hz}, 1 \mathrm{H}, \mathrm{CH}_{2} \mathrm{C}^{*}$ ), 2.58 (dd, $J=9.9,4.0 \mathrm{~Hz}, 1 \mathrm{H}, \mathrm{CH}_{2} \mathrm{C}^{*}$ ), 1.66 (s, $15 \mathrm{H}$, $\left.\left.\mathrm{C}_{5} \mathrm{Me}_{5}\right), 1.45\left(9 \mathrm{H}, \mathrm{Me}_{\mathrm{tBu}}\right) .{ }^{13} \mathrm{C}_{\{}{ }^{1} \mathrm{H}\right\} \mathrm{NMR}\left(125.8 \mathrm{MHz}, \mathrm{CDCl}_{3}, 298 \mathrm{~K}, \mathrm{ppm}\right): \delta 51.65$ (C $\left.{ }^{*}\right), 38.05\left(\mathrm{CH}_{2} \mathrm{Ph}\right), 37.56\left(\mathrm{CH}_{2} \mathrm{C}^{*}\right), 8.69\left(\mathrm{C}_{5} \mathrm{Me}_{5}\right)$. 
Isomer C, 9 \%. ${ }^{1} \mathrm{H} N M R\left(500.13 \mathrm{MHz}, \mathrm{CDCl}_{3}, 298 \mathrm{~K}, \mathrm{ppm}\right): \delta 4.62\left(\mathrm{~m}, 1 \mathrm{H}, \mathrm{CH}_{2} \mathrm{Ph}\right)$, 4.32 (br, 1H, C*H), 3.92 (d, $\left.J=12.5 \mathrm{~Hz}, 1 \mathrm{H}, \mathrm{CH}_{2} \mathrm{Ph}\right), 3.47\left(1 \mathrm{H}, \mathrm{CH}_{2} \mathrm{C}^{*}\right.$ ), 2.84 (pt, $J=$ $11.2 \mathrm{~Hz}, 1 \mathrm{H}, \mathrm{CH}_{2} \mathrm{C}^{*}$ ), 1.60 (s, $\left.15 \mathrm{H}, \mathrm{C}_{5} \mathrm{Me}_{5}\right), 1.45\left(9 \mathrm{H}, \mathrm{Me}_{t \mathrm{Bu}}\right) .{ }^{13} C\left\{{ }^{1} H\right\} N M R(125.8$ $\left.\mathrm{MHz}, \mathrm{CDCl}_{3}, 298 \mathrm{~K}, \mathrm{ppm}\right): \delta 52.69\left(\mathrm{C}^{*}\right), 35.41\left(\mathrm{CH}_{2} \mathrm{Ph}\right), 35.02\left(\mathrm{CH}_{2} \mathrm{C}^{*}\right), 8.49\left(\mathrm{C}_{5} \mathrm{Me}_{5}\right)$.

Isomer D, 8 \%. ${ }^{1} \mathrm{H} N M R\left(500.13 \mathrm{MHz}, \mathrm{CDCl}_{3}, 298 \mathrm{~K}, \mathrm{ppm}\right): \delta 4.62\left(\mathrm{~m}, 1 \mathrm{H}, \mathrm{CH}_{2} \mathrm{Ph}\right)$, $4.08\left(1 \mathrm{H}, \mathrm{CH}_{2} \mathrm{Ph}\right), 3.48\left(1 \mathrm{H}, \mathrm{C}^{*} \mathrm{H}\right), 2.66\left(\mathrm{dd}, J=13.0,4.4 \mathrm{~Hz}, 1 \mathrm{H}, \mathrm{CH}_{2} \mathrm{C}^{*}\right), 2.22(\mathrm{pt}, J=$ $13.0 \mathrm{~Hz}, 1 \mathrm{H}, \mathrm{CH}_{2} \mathrm{C}^{*}$ ), 1.71 (s, $\left.15 \mathrm{H}, \mathrm{C}_{5} \mathrm{Me}_{5}\right), 1.45\left(9 \mathrm{H}, \mathrm{Me}_{t \mathrm{Bu}}\right) .{ }^{13} C\left\{{ }^{1} \mathrm{H}\right\} N M R(125.8$ $\left.\mathrm{MHz}, \mathrm{CDCl}_{3}, 298 \mathrm{~K}, \mathrm{ppm}\right): \delta 50.72\left(\mathrm{C}^{*}\right), 37.44\left(\mathrm{CH}_{2} \mathrm{Ph}\right), 37.03\left(\mathrm{CH}_{2} \mathrm{C}^{*}\right), 9.06\left(\mathrm{C}_{5} \mathrm{Me}_{5}\right)$.

[( $\left.\left.\eta^{6}-\boldsymbol{p}-\mathrm{MeC}_{6} \mathbf{H}_{4} \mathbf{i P r}\right) \mathbf{R u C l}\left(\boldsymbol{\kappa}^{2} \mathbf{O}, \boldsymbol{S}-\mathrm{L} 3\right)\right]$ (5b). Yield: 79 \%. Isomeric ratio: 64/27/9. Anal. calcd for $\mathrm{C}_{25} \mathrm{H}_{34} \mathrm{ClNO}_{4} \mathrm{RuS}$ \% \%: C, 51.6; H, 5.9; N, 2.4; S, 5.5. Found, \%: C, 51.8; H, 6.0; N, 2.7; S, 5.7. IR (solid, $\left.\mathrm{cm}^{-1}\right): v\left(\mathrm{C}=\mathrm{O}_{\mathrm{Boc}}\right) 1763$ (s), 1701 (s), v(C=O) 1622 (s).

Isomer A, 64 \%. ${ }^{1} \mathrm{H}$ NMR (500.13 $\left.\mathrm{MHz}, \mathrm{CDCl}_{3}, 298 \mathrm{~K}, \mathrm{ppm}\right): \delta 7.63-7.34(\mathrm{~m}, 5 \mathrm{H}$, $\left.\mathrm{H}_{\mathrm{Ar}}\right), 6.03$ (br, 1H, NH), 5.94, 5.37, 5.03, $4.66\left(4 \times \mathrm{d}, J=5.9 \mathrm{~Hz}, 4 \mathrm{H}, \mathrm{H}_{\mathrm{A}}, \mathrm{H}_{\mathrm{B}}, \mathrm{H}_{\mathrm{A}^{\prime}}, \mathrm{H}_{\mathrm{B}^{\prime}}\right)$,

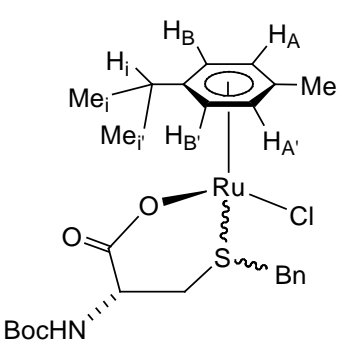
$4.77\left(\mathrm{AB}\right.$ system, $\left.J_{\mathrm{AB}}=11.7 \mathrm{~Hz}, 2 \mathrm{H}, \mathrm{CH}_{2} \mathrm{Ph}\right), 4.35\left(\mathrm{br}, 1 \mathrm{H}, \mathrm{C}^{*} \mathrm{H}\right)$, 3.17 (dd, $J=11.7,2.1 \mathrm{~Hz}, 1 \mathrm{H}, \mathrm{CH}_{2} \mathrm{C}^{*}$ ), 2.90 (sept, $J=6.7 \mathrm{~Hz}$, $\left.1 \mathrm{H}, \mathrm{H}_{\mathrm{i}}\right), 2.29$ (dd, $J=11.7,1.6 \mathrm{~Hz}, 1 \mathrm{H}, \mathrm{CH}_{2} \mathrm{C}^{*}$ ), 2.04 (s, 3H, Me), $1.41\left(\mathrm{~s}, 9 \mathrm{H}, \mathrm{Me}_{t \mathrm{Bu}}\right), 1.25,1.24\left(2 \times \mathrm{d}, J=6.9 \mathrm{~Hz}, 6 \mathrm{H}, \mathrm{Me}_{\mathrm{i}}, \mathrm{Me}_{\mathrm{i}^{\prime}}\right)$. ${ }^{13} \mathrm{C}\left\{{ }^{1} \mathrm{H}\right\} \operatorname{NMR}\left(125.8 \mathrm{MHz}, \mathrm{CDCl}_{3}, 298 \mathrm{~K}, \mathrm{ppm}\right): \delta 175.62(\mathrm{C}=\mathrm{O}), 155.14\left(\mathrm{C}=\mathrm{O}_{\mathrm{Boc}}\right)$, 134.06, 130.98, 128.54, $128.38\left(\mathrm{C}_{\mathrm{Ar}}\right), 106.65,101.28$ ( $\left.\mathrm{C}_{p \text {-cymene }}\right)$, 85.94, 84.63, 83.67, $80.53\left(\mathrm{CH}_{\mathrm{A}}, \mathrm{CH}_{\mathrm{B}}, \mathrm{CH}_{\mathrm{A}^{\prime}}, \mathrm{CH}_{\mathrm{B}^{\prime}}\right), 79.13\left(\mathrm{C}_{t \mathrm{Bu}}\right), 49.58$ (brs, $\left.\mathrm{C}^{*}\right), 38.71\left(\mathrm{CH}_{2} \mathrm{Ph}\right), 33.48$ (brs, $\left.\mathrm{CH}_{2} \mathrm{C}^{*}\right), 30.30\left(\mathrm{CH}_{\mathrm{i}}\right), 28.39\left(\mathrm{Me}_{\mathrm{tBu}}\right), 22.14,22.04\left(\mathrm{Me}_{\mathrm{i}}, \mathrm{Me}_{\mathrm{i}^{\prime}}\right), 18.01(\mathrm{Me})$.

Isomer B, 27 \%. ${ }^{1} \mathrm{H} N \mathrm{NM}$ (500.13 MHz, $\left.\mathrm{CDCl}_{3}, 298 \mathrm{~K}, \mathrm{ppm}\right): \delta 5.80$ (br, $\left.1 \mathrm{H}, \mathrm{NH}\right), 4.58$ (br, 1H, C ${ }^{*} \mathrm{H}$ ), 3.84 (AB system, $J_{\mathrm{AB}}=11.6 \mathrm{~Hz}, 2 \mathrm{H}, \mathrm{CH}_{2} \mathrm{Ph}$ ), 2.58 (br, $1 \mathrm{H}, \mathrm{H}_{\mathrm{i}}$ ), 2.17 (m, 2H, $\mathrm{CH}_{2} \mathrm{C}^{*}$ ),1.96 (br, 3H, Me), 1.48 (brs, 9H, Me $\mathrm{Bu}_{t \mathrm{Bu}}$ ), 1.18 (br, 6H, $\mathrm{Me}_{\mathrm{i}}, \mathrm{Me}_{\mathrm{i}}$ ). ${ }^{13} \mathrm{C}\left\{{ }^{1} \mathrm{H}\right\}$ 
NMR (125.8 MHz, $\left.\mathrm{CDCl}_{3}, 298 \mathrm{~K}, \mathrm{ppm}\right): \delta 49.58\left(\mathrm{C}^{*}\right), 41.43\left(\mathrm{CH}_{2} \mathrm{Ph}\right), 33.48$ (brs, $\left.\mathrm{CH}_{2} \mathrm{C}^{*}\right), 30.80\left(\mathrm{CH}_{\mathrm{i}}\right), 28.86$ (brs, $\left.\mathrm{Me}_{t \mathrm{Bu}}\right)$.

Isomer C, 9 \%. ${ }^{1} \mathrm{H} N M R\left(500.13 \mathrm{MHz}, \mathrm{CDCl}_{3}, 298 \mathrm{~K}, \mathrm{ppm}\right): \delta 7.63-7.34\left(\mathrm{~m}, 5 \mathrm{H}, \mathrm{H}_{\mathrm{Ar}}\right)$, 6.22 (br, 1H, NH), 5.49, 5.17, 4.90, $4.71\left(4 \times \mathrm{d}, J=5.8 \mathrm{~Hz}, 4 \mathrm{H}, \mathrm{H}_{\mathrm{A}}, \mathrm{H}_{\mathrm{B}}, \mathrm{H}_{\mathrm{A}^{\prime}}, \mathrm{H}_{\mathrm{B}^{\prime}}\right), 4.53$ $\left(1 \mathrm{H}, \mathrm{C}^{*} \mathrm{H}\right), 4.11\left(\mathrm{AB}\right.$ system, $\left.J_{\mathrm{AB}}=11.3 \mathrm{~Hz}, 2 \mathrm{H}, \mathrm{CH}_{2} \mathrm{Ph}\right), 3.22$ (d, $J=10.2 \mathrm{~Hz}, 1 \mathrm{H}$, $\mathrm{CH}_{2} \mathrm{C}^{*}$ ), 2.85 (m, 1H, $\mathrm{H}_{\mathrm{i}}$ ), 2.69 (pt, $J=11.1 \mathrm{~Hz}, 1 \mathrm{H}, \mathrm{CH}_{2} \mathrm{C}^{*}$ ), 2.13 (s, 3H, Me), 1.44 (s, 9H, $\mathrm{Me}_{t \mathrm{Bu}}$ ), $1.28\left(\mathrm{~m}, 6 \mathrm{H}, \mathrm{Me}_{\mathrm{i}}, \mathrm{Me}_{\mathrm{i}}{ }^{\prime}\right) .{ }^{13} \mathrm{C}\left\{{ }^{1} \mathrm{H}\right\} \mathrm{NMR}\left(125.8 \mathrm{MHz}, \mathrm{CDCl}_{3}, 298 \mathrm{~K}, \mathrm{ppm}\right): \delta$ $49.55\left(\mathrm{C}^{*}\right), 40.21\left(\mathrm{CH}_{2} \mathrm{Ph}\right), 35.69\left(\mathrm{CH}_{2} \mathrm{C}^{*}\right), 29.78\left(\mathrm{CH}_{\mathrm{i}}\right), 28.36\left(\mathrm{Me}_{t \mathrm{Bu}}\right), 18.22(\mathrm{Me})$.

Preparation of the complexes $\left[\left(\eta^{5}-\mathrm{C}_{5} \mathrm{Me}_{5}\right) \operatorname{Ir}\left(\kappa^{3} N, O, S-\mathrm{L}\right)\right]\left[\mathrm{SbF}_{6}\right](\mathrm{L}=\mathrm{L} 1(6 \mathrm{aSb})$, L2 (7aSb), L3 (8aSb)) and $\left[\left(\eta^{6}-p-\mathrm{MeC}_{6} \mathrm{H}_{4} \mathrm{PPr}\right) \mathrm{Ru}\left(\kappa^{3} N, O, S-\mathrm{L}\right)\right]\left[\mathrm{SbF}_{6}\right](\mathrm{L}=\mathrm{L} 1$ (6bSb), L2 (7bSb), L3 (8bSb)). To a solution of mixtures of 3 and $6 \mathrm{Cl}$ or 4 and $7 \mathrm{Cl}$ or pure $5(0.25 \mathrm{mmol})$ in $10 \mathrm{~mL}$ of acetone, $85.9 \mathrm{mg}(0.25 \mathrm{mmol})$ of $\mathrm{AgSbF}_{6}$ were added. After stirring for $1 \mathrm{~h}$, the AgCl formed was filtered off and the solution was concentrated under reduced pressure to $c a .3 \mathrm{~mL}$. The slow addition of $\mathrm{Et}_{2} \mathrm{O}$ led to the precipitation of a yellow solid which was washed with $\mathrm{Et}_{2} \mathrm{O}(3 \times 5 \mathrm{~mL})$ and vacuumdried. Yield: 6aSb, 72 \%; 6bSb, 81 \%; 7aSb, 69 \%; 7bSb, 73 \%; 8aSb, 63 \%; 8bSb, 51 $\%$.

The iridium complex 8aSb can be alternatively prepared as follows: To a solution of $\left[\left\{\left(\eta^{5}-\mathrm{C}_{5} \mathrm{Me}_{5}\right) \mathrm{IrCl}\right\}_{2}(\mu-\mathrm{Cl})_{2}\right](120.0 \mathrm{mg}, 0.15 \mathrm{mmol})$ in acetonitrile $(20 \mathrm{ml}), 207.4 \mathrm{mg}$ (0.60 mmol) of $\mathrm{AgSbF}_{6}$ and $100 \mathrm{mg}$ of $4 \AA$ MS were added. The immediate precipitation of a white-grey coloured solid was observed. After stirring at room temperature for $3 \mathrm{~h}$, the light yellow solution was filtered and $93.9 \mathrm{mg}(0.30 \mathrm{mmol})$ of $S$-Bn- $N H$-Boc- $L$-Cys (7) and $25.3 \mathrm{mg}(0.30 \mathrm{mmol})$ of $\mathrm{NaHCO}_{3}$ were added. After stirring for $1 \mathrm{~h}$, the solvent was evaporated and the residue extracted in $\mathrm{CH}_{2} \mathrm{Cl}_{2}(4 \times 5 \mathrm{ml})$. The resulting solution was filtered and the filtrate was concentrated to ca $3 \mathrm{ml}$. The addition of $20 \mathrm{ml}$ of 
hexane afforded $\mathbf{8 a S b}$ as a yellow solid which was filtered off and vacuum-dried. Yield $63 \%$.

$\left[\left(\boldsymbol{\eta}^{5}-\mathrm{C}_{5} \mathbf{M e}_{5}\right) \operatorname{Ir}\left(\boldsymbol{\kappa}^{3} \boldsymbol{N}, \boldsymbol{O}, \boldsymbol{S}-\mathbf{L} 1\right)\right]\left[\mathrm{SbF}_{\mathbf{6}}\right](\mathbf{6 a S b})$. Anal. ${ }^{20}$ calcd for $\mathrm{C}_{20} \mathrm{H}_{27} \mathrm{~F}_{6} \mathrm{IrNO}_{2} \mathrm{SSb} \cdot 3 \mathrm{H}_{2} \mathrm{O}$, \%: C, 29.0; H, 4.0; N, 1.7; S, 3.9. Found, \%: C, 29.1; H, 3.8; N, 1.4; S, 3.7. IR (solid, $\left.\mathrm{cm}^{-1}\right): v(\mathrm{C}=\mathrm{O}) 1654(\mathrm{~s}), 1635$ (s), $v\left(\mathrm{SbF}_{6}\right) 650$ (s). CD (acetone, $\left.4.4 \times 10^{-4} \mathrm{M}, 298 \mathrm{~K}\right)$ : $\lambda, \mathrm{nm},(\Delta \varepsilon): 335(-5.22)$.

$R_{\mathrm{Ir}}, R_{\mathrm{C}}, S_{\mathrm{S}}$ diastereomer. ${ }^{1} \mathrm{H} \mathrm{NMR}\left(300.13 \mathrm{MHz}\right.$, acetone- $\left.\mathrm{d}_{6}, 298 \mathrm{~K}, \mathrm{ppm}\right): \delta 7.54-7.32$ (m, 5H, $\mathrm{H}_{\mathrm{Ar}}$ ), 6.32 (br, 1H, NH), 5.40 (br, 1H, NH), 4.32 (brs, $\left.1 \mathrm{H}, \mathrm{C}^{*} \mathrm{H}\right), 4.16(\mathrm{AB}$

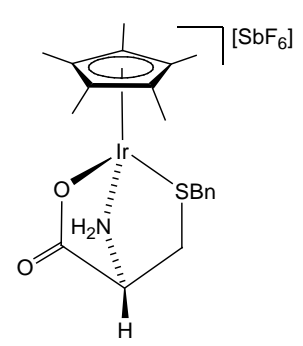
system, $\left.J_{\mathrm{AB}}=12.9 \mathrm{~Hz}, 2 \mathrm{H}, \mathrm{CH}_{2} \mathrm{Ph}\right), 2.83(\mathrm{AB}$ part, $\mathrm{ABX}$ system, $J_{\mathrm{AB}}=14.5 \mathrm{~Hz}, J_{\mathrm{AX}}=3.7 \mathrm{~Hz}, 2 \mathrm{H}, \mathrm{CH}_{2} \mathrm{C}^{*}$ ), 1.92 (s, 15H, $\mathrm{C}_{5} \mathrm{Me}_{5}$ ). ${ }^{13} C\left\{{ }^{1} \mathrm{H}\right\}$ NMR (75.47 MHz, acetone-d $\left.6,298 \mathrm{~K}, \mathrm{ppm}\right): \delta 177.00$ $(\mathrm{C}=\mathrm{O}), 132.95,130.46,129.18,128.89\left(\mathrm{C}_{\mathrm{Ar}}\right), 89.52\left(5 \mathrm{C}, C_{5} \mathrm{Me}_{5}\right)$, $60.36\left(\mathrm{C}^{*}\right), 39.14\left(\mathrm{CH}_{2} \mathrm{Ph}\right), 31.37\left(\mathrm{CH}_{2} \mathrm{C}^{*}\right), 8.25\left(\mathrm{C}_{5} \mathrm{Me}_{5}\right)$.

$\left[\left(\eta^{6}-p-\mathrm{MeC}_{6} \mathbf{H}_{4} i \mathrm{Pr}\right) \mathrm{Ru}\left(\boldsymbol{\kappa}^{3} \boldsymbol{N}, \boldsymbol{O}, \boldsymbol{S}-\mathbf{L} 1\right)\right]\left[\mathrm{SbF}_{6}\right](\mathbf{6 b S b})$. Isomeric ratio: 95/5. Anal. calcd for $\mathrm{C}_{20} \mathrm{H}_{26} \mathrm{~F}_{6} \mathrm{NO}_{2} \mathrm{RuSSb}$ \%: C, 35.3; $\mathrm{H}, 3.9 ; \mathrm{N}, 2.1 ; \mathrm{S}$, 4.7. Found, \%: C, 35.7; H, 3.9; N, 2.0; S, 4.7. IR (solid, $\left.\mathrm{cm}^{-1}\right): v(\mathrm{C}=\mathrm{O}) 1658$ (s), 1623 (s), v( $\left.\mathrm{SbF}_{6}\right) 653$ (s). CD (acetone, $\left.4.9 \times 10^{-4} \mathrm{M}, 298 \mathrm{~K}\right): \lambda, \mathrm{nm},(\Delta \varepsilon): 334(-0.75)$.

$R_{\mathrm{Ru}}, R_{\mathrm{C}}, S_{\mathrm{S}}$ diastereomer (95 \%). ${ }^{1} \mathrm{H} N \mathrm{NMR}\left(300.13 \mathrm{MHz}\right.$, acetone- $\left.\mathrm{d}_{6}, 298 \mathrm{~K}, \mathrm{ppm}\right): \delta 7.58$ - $7.40\left(\mathrm{~m}, 5 \mathrm{H}, \mathrm{H}_{\mathrm{Ar}}\right), 6.29(\mathrm{br}, 1 \mathrm{H}, \mathrm{NH}), 5.82,5.79,5.58\left(3 \times \mathrm{d}, J=5.7 \mathrm{~Hz}, 4 \mathrm{H}, \mathrm{H}_{\mathrm{A}}, \mathrm{H}_{\mathrm{B}}\right.$, $\left.2 \mathrm{H}, \mathrm{CH}_{2} \mathrm{Ph}\right), 3.85\left(\mathrm{brs}, 1 \mathrm{H}, \mathrm{C}^{*} \mathrm{H}\right), 2.78,2.51\left(2 \times \mathrm{m}, 3 \mathrm{H}, \mathrm{H}_{\mathrm{i}}\right.$,
$\left.4.0 \mathrm{~Hz}, 6 \mathrm{H}, \mathrm{Me}_{\mathrm{i}}, \mathrm{Me}_{\mathrm{i}^{\prime}}\right) \cdot{ }^{13} \mathrm{C}\left\{{ }^{1} \mathrm{H}\right\} \mathrm{NMR}\left(75.47 \mathrm{MHz}\right.$, acetone-d $\mathrm{d}_{6}$, 
298 K, ppm): $\delta 175.81$ (C=O), 133.82, 130.42, 129.17, $128.98\left(\mathrm{C}_{\mathrm{Ar}}\right), 106.28,99.42(2 \mathrm{C}$, C $\left(\mathrm{CH}_{2} \mathrm{Ph}\right), 31.05\left(\mathrm{CH}_{2} \mathrm{C}^{*}\right), 31.04\left(\mathrm{CH}_{\mathrm{i}}\right), 21.79,21.46\left(\mathrm{Me}_{\mathrm{i}}, \mathrm{Me}_{\mathrm{i}}\right)$, $17.32(\mathrm{Me})$.

$R_{\mathrm{Ru}}, R_{\mathrm{C}}, R_{\mathrm{S}}$ diastereomer (5 \%). ${ }^{1} \mathrm{H}$ NMR (300.13 MHz, acetone- $\left.\mathrm{d}_{6}, 298 \mathrm{~K}, \mathrm{ppm}\right): \delta 6.06$, 5.66, 5.50, $4.88\left(4 \times\right.$ brs, $\left.4 \mathrm{H}, \mathrm{H}_{\mathrm{A}}, \mathrm{H}_{\mathrm{B}}, \mathrm{H}_{\mathrm{A}^{\prime}}, \mathrm{H}_{\mathrm{B}^{\prime}}\right), 4.37$ (d, $\left.J=11.3 \mathrm{~Hz}, 1 \mathrm{H}, \mathrm{CH}_{2} \mathrm{Ph}\right), 4.15$ (1H, $\mathrm{CH}_{2} \mathrm{Ph}$ ), $3.85\left(1 \mathrm{H}, \mathrm{C}^{*} \mathrm{H}\right), 1.94$ (s, 3H, Me), $1.30\left(6 \mathrm{H}, \mathrm{Me}_{\mathrm{i}}, \mathrm{Me}_{\mathrm{i}}\right) .{ }^{13} C\left\{{ }^{1} \mathrm{H}\right\} N M R$ (75.47 MHz, acetone- $d_{6}, 298 \mathrm{~K}$, ppm): $\delta 59.08\left(\mathrm{C}^{*}\right), 17.22(\mathrm{Me})$.

$\left[\left(\eta^{5}-\mathrm{C}_{5} \mathbf{M e}_{5}\right) \operatorname{Ir}\left(\boldsymbol{\kappa}^{3} \boldsymbol{N}, \boldsymbol{O}, \boldsymbol{S}-\mathbf{L} 2\right)\right]\left[\mathrm{SbF}_{6}\right]$ (7aSb). Anal. calcd for $\mathrm{C}_{21} \mathrm{H}_{29} \mathrm{~F}_{6} \operatorname{IrNO}_{2} \mathrm{SSb}, \%$ : C, 32.0; H, 3.7; N, 1.8; S, 4.1. Found, \%: C, 32.4; H, 3.9; N, 1.8; S, 3.8. IR (solid, $\mathrm{cm}^{-1}$ ): $v(\mathrm{C}=\mathrm{O}) 1655$ (s), 1635 (s), v( $\left.\mathrm{SbF}_{6}\right) 651$ (s). CD (acetone, $\left.5.0 \times 10^{-4} \mathrm{M}, 298 \mathrm{~K}\right): \lambda, \mathrm{nm}$, $(\Delta \varepsilon): 333(-4.63)$

$R_{\mathrm{Ir}}, R_{\mathrm{C}}, S_{\mathrm{S}}$ diastereomer. ${ }^{1} \mathrm{H}$ NMR (400.16 MHz, acetone- $\left.\mathrm{d}_{6}, 298 \mathrm{~K}, \mathrm{ppm}\right): \delta 7.43-7.27$ (m, 5H, $\mathrm{H}_{\mathrm{Ar}}$ ), 6.01 (br, 1H, NH), 5.64 (br, 1H, NH), 4.09 (AB system, $J_{\mathrm{AB}}=12.9 \mathrm{~Hz}$, $\left.2 \mathrm{H}, \mathrm{CH}_{2} \mathrm{Ph}\right), 2.66\left(\mathrm{AB}\right.$ part, $\mathrm{ABX}$ system, $J_{\mathrm{AB}}=14.4 \mathrm{~Hz}, J_{\mathrm{AX}}=$ $65.82\left(\mathrm{C}^{*}\right), 39.02\left(\mathrm{CH}_{2} \mathrm{Ph}\right), 35.84\left(\mathrm{CH}_{2} \mathrm{C}^{*}\right), 22.11\left(\mathrm{C}^{*} \mathrm{Me}\right), 8.25\left(\mathrm{C}_{5} \mathrm{Me}_{5}\right)$.

$\left[\left(\eta^{6}-p-\mathrm{MeC}_{6} \mathbf{H}_{4} \mathbf{i P r}\right) \operatorname{Ru}\left(\boldsymbol{\kappa}^{3} N, \boldsymbol{O}, \boldsymbol{S}-\mathrm{L} 2\right)\right]\left[\mathrm{SbF}_{6}\right]$ (7bSb). Isomeric ratio: $\geq 97 / 3$. Anal. ${ }^{20}$ calcd for $\mathrm{C}_{21} \mathrm{H}_{28} \mathrm{~F}_{6} \mathrm{NO}_{2} \mathrm{RuSSb} \cdot 3 \mathrm{H}_{2} \mathrm{O}$, \%: C, 33.6; H, 4.5; N, 1.9; S, 4.3. Found, \%: C, 33.2; H, 4.3; N, 1.5; S, 4.1. IR (solid, $\mathrm{cm}^{-1}$ ): $v(\mathrm{C}=\mathrm{O}) 1645$ (s), $v\left(\mathrm{SbF}_{6}\right) 652$ (s). CD (acetone, $\left.4.9 \times 10^{-4} \mathrm{M}, 298 \mathrm{~K}\right): \lambda, \mathrm{nm},(\Delta \varepsilon): 334(-1.18)$.

$R_{\mathrm{Ru}}, R_{\mathrm{C}}, S_{\mathrm{S}}$ diastereomer ( $\left.\geq 97 \%\right) .{ }^{1} \mathrm{H} N \mathrm{NMR}\left(400.16 \mathrm{MHz}\right.$, acetone- $\left.d_{6}, 298 \mathrm{~K}, \mathrm{ppm}\right): \delta$ $7.52-7.27\left(\mathrm{~m}, 5 \mathrm{H}, \mathrm{H}_{\mathrm{Ar}}\right), 6.06(\mathrm{br}, 1 \mathrm{H}, \mathrm{NH}), 5.75,5.58,5.52,5.48(4 \times \mathrm{d}, J=5.8 \mathrm{~Hz}$, 
$4 \mathrm{H}, \mathrm{H}_{\mathrm{A}}, \mathrm{H}_{\mathrm{B}}, \mathrm{H}_{\mathrm{A}^{\prime}}, \mathrm{H}_{\mathrm{B}^{\prime}}$ ), 5.34 (br, $1 \mathrm{H}, \mathrm{NH}$ ), 4.02 (AB system, $J_{\mathrm{AB}}=12.0 \mathrm{~Hz}, 2 \mathrm{H}, \mathrm{CH}_{2} \mathrm{Ph}$ ),

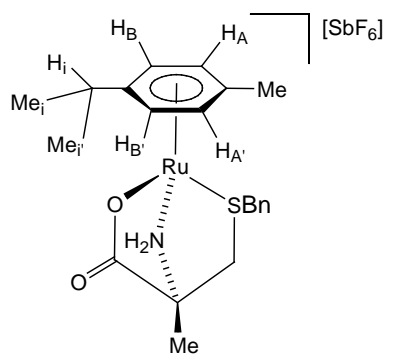

2.68 (sept, $J=6.9 \mathrm{~Hz}, 1 \mathrm{H}, \mathrm{H}_{\mathrm{i}}$ ), 2.53 (AB part, ABX system, $\left.J_{\mathrm{AB}}=14.3 \mathrm{~Hz}, J_{\mathrm{AX}}=2.6 \mathrm{~Hz}, 2 \mathrm{H}, \mathrm{CH}_{2} \mathrm{C}^{*}\right), 2.10$ (s, 3H, Me), 1.37 (s, 3H, C Me), 1.23 (br, 6H, $\left.\mathrm{Me}_{\mathrm{i}}, \mathrm{Me}_{\mathrm{i}}{ }^{\prime}\right) .{ }^{13} \mathrm{C}\left\{{ }^{1} \mathrm{H}\right\} N M R$ (100.6 MHz, acetone- $\left.d_{6}, 298 \mathrm{~K}, \mathrm{ppm}\right): \delta 176.51(\mathrm{C}=\mathrm{O})$, 133.79, 130.38, 129.17, 128.96 ( $\left.\mathrm{C}_{\mathrm{Ar}}\right), 105.86,100.01$ ( $\left.\mathrm{C}_{p \text {-cymene }}\right), 84.27,83.60,82.85$, 81.96 $\left(\mathrm{CH}_{\mathrm{A}}, \mathrm{CH}_{\mathrm{B}}, \mathrm{CH}_{\mathrm{A}^{\prime}}, \mathrm{CH}_{\mathrm{B}^{\prime}}\right), 64.31\left(\mathrm{C}^{*}\right), 41.24\left(\mathrm{CH}_{2} \mathrm{Ph}\right), 35.98\left(\mathrm{CH}_{2} \mathrm{C}^{*}\right), 31.07\left(\mathrm{CH}_{\mathrm{i}}\right)$, $22.43\left(\mathrm{C}^{*} \mathrm{Me}\right), 21.93,21.31\left(2 \mathrm{C}, \mathrm{Me}_{\mathrm{i}}, \mathrm{Me}_{\mathrm{i}^{\prime}}\right), 17.17(\mathrm{Me})$.

$\left[\left(\boldsymbol{\eta}^{5}-\mathrm{C}_{5} \mathbf{M e}_{5}\right) \operatorname{Ir}\left(\boldsymbol{\kappa}^{3} \boldsymbol{N}, \boldsymbol{O}, \boldsymbol{S}-\mathbf{L} 3\right)\right]\left[\mathrm{SbF}_{\mathbf{6}}\right](\mathbf{8 a S b})$. Anal. ${ }^{20}$ calcd for $\mathrm{C}_{25} \mathrm{H}_{35} \mathrm{~F}_{6} \mathrm{IrNO}_{4} \mathrm{SSb} \cdot \mathrm{H}_{2} \mathrm{O}$, \%: C, 33.6; H, 4.1; N, 1.6; S, 3.6. Found, \%: C, 33.3; H, 4.3; N, 1.9; S, 4.0. IR (solid, $\left.\mathrm{cm}^{-1}\right): v\left(\mathrm{C}=\mathrm{O}_{\mathrm{Boc}}\right) 1762(\mathrm{~s}), 1698(\mathrm{~s}), v(\mathrm{C}=\mathrm{O}) 1629(\mathrm{~s}), v\left(\mathrm{SbF}_{6}\right) 651$ (s). CD (acetone, 5.1 $\left.\times 10^{-4} \mathrm{M}, 298 \mathrm{~K}\right): \lambda, \mathrm{nm},(\Delta \varepsilon): 332(-4.23)$.

$R_{\mathrm{II}}, R_{\mathrm{C}}, S_{\mathrm{S}}$ diastereomer (82 \%). ${ }^{1} \mathrm{H} \mathrm{NMR}\left(500.13 \mathrm{MHz}, \mathrm{CD}_{2} \mathrm{Cl}_{2}, 298 \mathrm{~K}, \mathrm{ppm}\right): \delta 7.52$ 7.31 (m, 5H, $\mathrm{H}_{\mathrm{Ar}}$ ), 5.69 (brs, 1H, NH), 4.43 (brs, 1H, C ${ }^{*} \mathrm{H}$ ), 3.96 (brs, 2H, $\mathrm{CH}_{2} \mathrm{Ph}$ ), 2.90

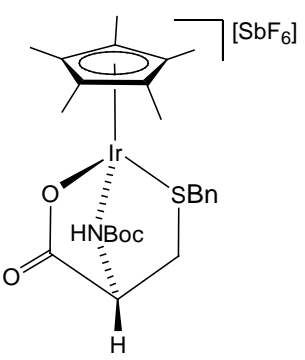

(AB system, $J_{\mathrm{AB}}=13.0 \mathrm{~Hz}, 2 \mathrm{H}, \mathrm{CH}_{2} \mathrm{C}^{*}$ ), 1.84 (s, $15 \mathrm{H}, \mathrm{C}_{5} \mathrm{Me}_{5}$ ), 1.61 (s, 9H, Me $\left.\mathrm{tBu}_{\mathrm{Bu}}\right){ }^{13} \mathrm{C}\left\{{ }^{1} \mathrm{H}\right\} \mathrm{NMR}\left(125.8 \mathrm{MHz}, \mathrm{CD}_{2} \mathrm{Cl}_{2}, 298 \mathrm{~K}, \mathrm{ppm}\right): \delta$ 131.88, 130.40, 129.46, 129.30 ( $4 \times$ brs, $\mathrm{C}_{\mathrm{Ar}}$ ), 90.24 (brs, $C_{5} \mathrm{Me}_{5}$ ), 64.18 (brs, $\mathrm{C}^{*}$ ), 39.85 (brs, $\mathrm{CH}_{2} \mathrm{Ph}$ ), 28.13 (brs, $\mathrm{CH}_{2} \mathrm{C}^{*}$ ), 27.72 (brs, $\mathrm{Me}_{t \mathrm{Bu}}$ ), 8.78 (brs, $\mathrm{C}_{5} \mathrm{Me}_{5}$ ).

Solvate derivative (18\%). ${ }^{1} \mathrm{H} N M R\left(500.13 \mathrm{MHz}, \mathrm{CD}_{2} \mathrm{Cl}_{2}, 298 \mathrm{~K}, \mathrm{ppm}\right): \delta 1.49$ (brs, 9H, $\mathrm{Me}_{t \mathrm{Bu}}$ ), 1.40 (brs, 15H, C $\left.{ }_{5} \mathrm{Me}_{5}\right) \cdot{ }^{13} C\left\{{ }^{1} \mathrm{H}\right\} \mathrm{NMR}\left(125.8 \mathrm{MHz}, \mathrm{CD}_{2} \mathrm{Cl}_{2}, 298 \mathrm{~K}, \mathrm{ppm}\right.$ ): $\delta$ 90.14 (brs, $C_{5} \mathrm{Me}_{5}$ ), 64.18 (brs, $\mathrm{C}^{*}$ ), 28.01 (brs, $\mathrm{Me}_{t \mathrm{Bu}}$ ), 7.88 (brs, $\mathrm{C}_{5} \mathrm{Me}_{5}$ ).

$\left[\left(\eta^{6}-p-\mathrm{MeC}_{6} \mathrm{H}_{4} i \mathrm{Pr}\right) \operatorname{Ru}\left(\kappa^{3} N, O, S-\mathrm{L} 3\right)\right]\left[\mathrm{SbF}_{6}\right] \quad(8 \mathrm{bSb}) . \quad$ Anal. calcd for $\mathrm{C}_{25} \mathrm{H}_{34} \mathrm{~F}_{6} \mathrm{NO}_{4} \mathrm{RuSSb}$ \%: C, 38.4; H, 4.4; N, 1.8; S, 4.1. Found, \%: C, 38.6; H, 4.5; N, 
2.0; S, 4.4. IR (solid, $\left.\mathrm{cm}^{-1}\right): v\left(\mathrm{C}=\mathrm{O}_{\mathrm{Boc}}\right) 1760$ (s), $v(\mathrm{C}=\mathrm{O}) 1637$ (s), $v\left(\mathrm{SbF}_{6}\right) 653$ (s). CD (acetone, $\left.5.0 \times 10^{-4} \mathrm{M}, 298 \mathrm{~K}\right): \lambda, \mathrm{nm},(\Delta \varepsilon): 401(-2.93)$.

$R_{\mathrm{Ru}}, R_{\mathrm{C}}, S_{\mathrm{S}}$ diastereomer. ${ }^{1} \mathrm{H}$ NMR (400.16 MHz, acetone- $\left.\mathrm{d}_{6}, 298 \mathrm{~K}, \mathrm{ppm}\right)^{\mathrm{a}}: \delta 7.47$ (br, 1H, NH), $7.34-7.22$ (m, 5H, $\mathrm{H}_{\mathrm{Ar}}$ ), 5.27, 5.13, 5.01 (3 × br, 4H, $\mathrm{H}_{\mathrm{A}}, \mathrm{H}_{\mathrm{B}}, \mathrm{H}_{\mathrm{A}^{\prime}}, \mathrm{H}_{\mathrm{B}^{\prime}}$ ), 3.84

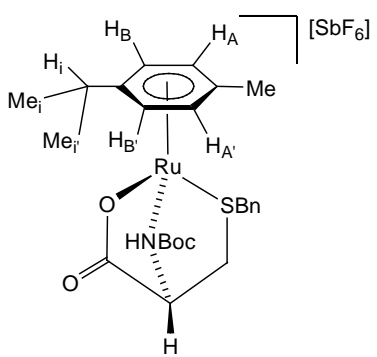

(AB system, $J_{\mathrm{AB}}=11.5 \mathrm{~Hz}, 2 \mathrm{H}, \mathrm{CH}_{2} \mathrm{Ph}$ ), 3.67 (br, $1 \mathrm{H}, \mathrm{C}^{*} \mathrm{H}$ ), $2.59\left(\mathrm{AB}\right.$ system, $\left.J_{\mathrm{AB}}=15.2 \mathrm{~Hz}, 2 \mathrm{H}, \mathrm{CH}_{2} \mathrm{C}^{*}\right), 2.49\left(\mathrm{~m}, 1 \mathrm{H}, \mathrm{H}_{\mathrm{i}}\right)$, 1.94 (s, 3H, Me), 1.43 (s, 9H, $\left.\mathrm{Me}_{t \mathrm{Bu}}\right)$ 1.07, $1.05(2 \times \mathrm{d}, J=6.6$ $\left.\mathrm{Hz}, 6 \mathrm{H}, \mathrm{Me}_{\mathrm{i}}, \mathrm{Me}_{\mathrm{i}^{\prime}}\right) .{ }^{13} \mathrm{C}\left\{{ }^{1} \mathrm{H}\right\} N \mathrm{NMR}\left(100.6 \mathrm{MHz}\right.$, acetone- $\mathrm{d}_{6}, 298$ K, ppm): $\delta 177.10(\mathrm{C}=\mathrm{O}), 132.92,130.28,129.28,129.12\left(6 \mathrm{C}, \mathrm{C}_{\mathrm{Ar}}\right), 107.02,99.08(2 \mathrm{C}$,

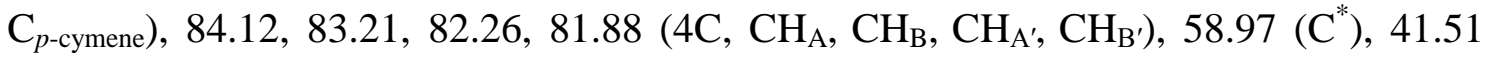
( $\left.\mathrm{CH}_{2} \mathrm{Ph}\right), 31.81\left(\mathrm{CH}_{2} \mathrm{C}^{*}\right), 31.01$ (3C, $\left.\mathrm{Me}_{t \mathrm{Bu}}\right), 28.17\left(\mathrm{CH}_{\mathrm{i}}\right), 22.17,21.90$ (2C, $\left.\mathrm{Me}_{\mathrm{i}}, \mathrm{Me}_{\mathrm{i}}{ }^{\prime}\right)$, $17.77(\mathrm{Me})$.

Preparation of the complexes $\left[\left(\eta^{5}-\mathrm{C}_{5} \mathrm{Me}_{5}\right) \operatorname{Ir}\left(\kappa^{3} N, O, S-\mathrm{L} 3_{-\mathrm{H}}\right)\right](9 \mathrm{a})$ and $\left[\left(\eta^{6}-p\right.\right.$ $\left.\left.\mathrm{MeC}_{6} \mathrm{H}_{4} i \mathrm{Pr}\right) \mathrm{Ru}\left(\boldsymbol{\kappa}^{3} \boldsymbol{N}, \boldsymbol{O}, S_{-} \mathbf{L}_{-\mathrm{H}}\right)\right]$ (9b). At room temperature, to a suspension of the corresponding 8Sb complex (0.17 mmol), $14.3 \mathrm{mg}(0.17 \mathrm{mmol})$ of $\mathrm{NaHCO}_{3}$ were added. The suspension was vigorously stirred for $3 \mathrm{~h}$ and then was concentrated under reduced pressure until dryness. The residue was extracted with $\mathrm{CH}_{2} \mathrm{Cl}_{2}(4 \times 5 \mathrm{~mL})$ and the resulting solution was concentrated under reduced pressure to ca. $1 \mathrm{~mL}$. The slow addition of $n$-hexane led to the precipitation of a yellow solid which was washed with $n$ hexane (4 × $5 \mathrm{~mL})$ and vacuum-dried. Yield: $65 \%$ (9a), $72 \%$ (9b). Alternatively, complexes 9a and 9b can be prepared as follows: at $298 \mathrm{~K}$, to a suspension of the corresponding dimer $\left[\left\{\left(\eta^{\mathrm{n}} \text {-ring }\right) \mathrm{MCl}\right\}_{2}(\mu-\mathrm{Cl})_{2}\right](0.32 \mathrm{mmol})$, in $10 \mathrm{~mL}$ of $\mathrm{MeOH}, 201.5$ mg (0.64 mmol) of HL3 were added. The resulting yellow (Ir) or orange (Ru) solution was stirred for $15 \mathrm{~min}$ and then $108.7 \mathrm{mg}(1.29 \mathrm{mmol})$ of $\mathrm{NaHCO}_{3}$ were added. The resulting suspension was vigorously stirred for $2 \mathrm{~h}$ and then was concentrated under 
reduced pressure until dryness. The residue was extracted with $\mathrm{CH}_{2} \mathrm{Cl}_{2}(4 \times 5 \mathrm{~mL})$ and the resulting solution was concentrated under reduced pressure to $c a$. $3 \mathrm{~mL}$. The slow addition of $n$-hexane led to the precipitation of a yellow (Ir) or orange (Ru) solid which was washed with $n$-hexane (4 × 5 mL) and vacuum-dried. Yield: $56 \%$ (9a), 73 \% (9b).

$\left[\left(\boldsymbol{\eta}^{5}-\mathrm{C}_{5} \mathbf{M e}_{5}\right) \operatorname{Ir}\left(\boldsymbol{\kappa}^{3} \boldsymbol{N}, \boldsymbol{O}, \boldsymbol{S}-\mathbf{L} 3_{-\mathrm{H}}\right)\right]$ (9a). Anal. ${ }^{20}$ calcd for $\mathrm{C}_{25} \mathrm{H}_{34} \mathrm{IrNO}_{4} \mathrm{~S} \cdot \mathrm{H}_{2} \mathrm{O}, \%$ : C, 45.8; H, 5.5; N, 2.1; S, 4.9. Found, \%: C, 45.7; H, 5.4; N, 2.2; S, 4.9. IR (solid, $\mathrm{cm}^{-1}$ ): $v\left(\mathrm{C}=\mathrm{O}_{\text {Bос }}\right) 1763(\mathrm{~s}), v(\mathrm{C}=\mathrm{O}) 1642$ (s). $\mathrm{CD}$ (acetone, $\left.3.2 \times 10^{-4} \mathrm{M}, 298 \mathrm{~K}\right): \lambda, \mathrm{nm},(\Delta \varepsilon)$ : $352(-4.01)$.

$R_{\mathrm{Ir}}, R_{\mathrm{C}}$ diastereomers. ${ }^{1} \mathrm{H} N \mathrm{NM}\left(500.13 \mathrm{MHz}, \mathrm{CDCl}_{3}, 298 \mathrm{~K}, \mathrm{ppm}\right): \delta 7.40-7.31$ (m, 5H,

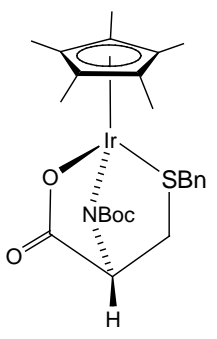
$\mathrm{H}_{\mathrm{Ar}}$ ), 5.07 (br, $1 \mathrm{H}, \mathrm{C}^{*} \mathrm{H}$ ), 3.97 (AB system, $J_{\mathrm{AB}}=13.4 \mathrm{~Hz}, 2 \mathrm{H}, \mathrm{CH}_{2} \mathrm{Ph}$ ), 2.14 (dd, $J=13.0,4.5 \mathrm{~Hz}, 1 \mathrm{H}, \mathrm{CH}_{2} \mathrm{C}^{*}$ ), 1.96 (dd, $J=13.0,0.8 \mathrm{~Hz}, 1 \mathrm{H}$, $\mathrm{CH}_{2} \mathrm{C}^{*}$ ), 1.93 (s, 15H, $\left.\mathrm{C}_{5} \mathrm{Me}_{5}\right), 1.39$ (s, 9H, $\left.\mathrm{Me}_{t \mathrm{Bu}}\right) .{ }^{13} \mathrm{C}\left\{{ }^{1} \mathrm{H}\right\} N \mathrm{NMR}(125.8$

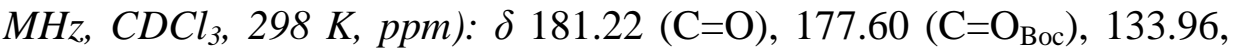
130.01, 129.07, $128.45\left(\mathrm{C}_{\mathrm{Ar}}\right), 110.07\left(\mathrm{C}_{5} \mathrm{Me}_{5}\right), 87.94\left(\mathrm{C}_{t \mathrm{Bu}}\right), 68.77\left(\mathrm{C}^{*}\right), 39.80\left(\mathrm{CH}_{2} \mathrm{Ph}\right)$, $32.00\left(\mathrm{CH}_{2} \mathrm{C}^{*}\right), 28.69\left(\mathrm{Me}_{t \mathrm{Bu}}\right) 9.40\left(\mathrm{C}_{5} \mathrm{Me}_{5}\right)$.

[( $\left.\left.\boldsymbol{\eta}^{6}-\boldsymbol{p}-\mathrm{MeC}_{6} \mathbf{H}_{4} \boldsymbol{i} \mathbf{P r}\right) \operatorname{Ru}\left(\boldsymbol{\kappa}^{3} \boldsymbol{N}, \boldsymbol{O}, \boldsymbol{S}-\mathbf{L} 3_{-\mathrm{H}}\right)\right]$ (9b). Isomeric ratio: 68/32. Anal. calcd for $\mathrm{C}_{25} \mathrm{H}_{33} \mathrm{NO}_{4} \mathrm{RuS} \cdot \mathrm{H}_{2} \mathrm{O}$, \%: C, 53.3; H, 6.2; N, 2.5; S, 5.7. Found, \%: C, 53.5; H, 5.8; N, 2.7; S, 5.7. IR (solid, $\mathrm{cm}^{-1}$ ): $v(\mathrm{C}=\mathrm{O}) 1623$ (s).

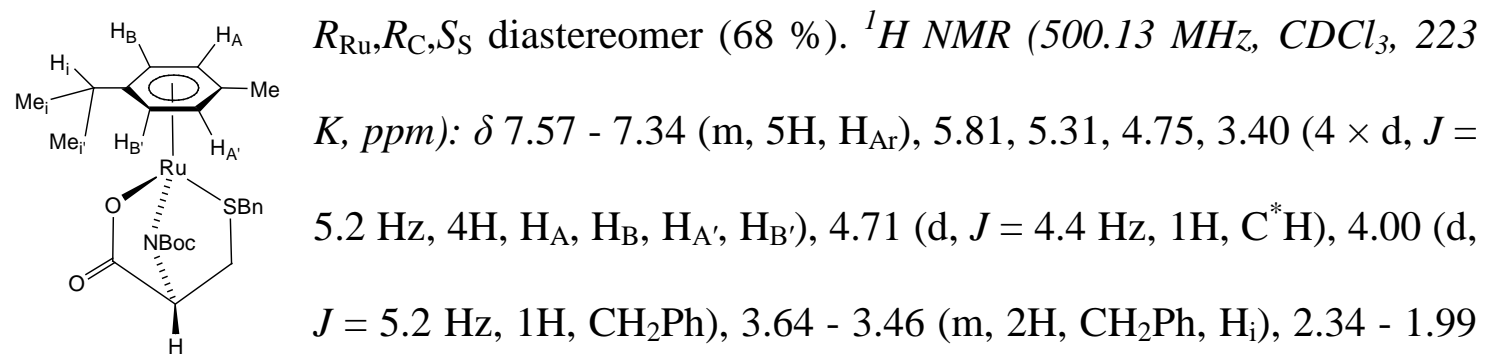
(m, 2H, $\mathrm{CH}_{2} \mathrm{C}^{*}$ ), 2.18 (s, 3H, Me), 1.51 (brs, 9H, Me $\left.{ }_{t B u}\right)$ 1.23, $1.18(2 \times \mathrm{d}, J=6.8 \mathrm{~Hz}$, 6H, $\left.\mathrm{Me}_{\mathrm{i}}, \mathrm{Me}_{\mathrm{i}^{\prime}}\right) .{ }^{13} C\left\{{ }^{1} \mathrm{H}\right\} \operatorname{NMR}\left(125.8 \mathrm{MHz}, \mathrm{CDCl}_{3}, 223 \mathrm{~K}, \mathrm{ppm}\right): \delta 180.86(\mathrm{C}=\mathrm{O})$, $161.30\left(\mathrm{C}=\mathrm{O}_{\text {Boc }}\right), 134.52,130.50,129.20,129.15\left(\mathrm{C}_{\mathrm{Ar}}\right), 101.73,98.02\left(\mathrm{C}_{p \text {-cymene }}\right), 84.24$, 
83.80, 81.89, $79.38\left(\mathrm{CH}_{\mathrm{A}}, \mathrm{CH}_{\mathrm{B}}, \mathrm{CH}_{\mathrm{A}^{\prime}}, \mathrm{CH}_{\mathrm{B}^{\prime}}\right), 78.04\left(\mathrm{C}_{t \mathrm{Bu}}\right), 65.57\left(\mathrm{C}^{*}\right), 41.23\left(\mathrm{CH}_{2} \mathrm{Ph}\right)$, 32.57 $\left(\mathrm{CH}_{2} \mathrm{C}^{*}\right)$, $31.09\left(\mathrm{CH}_{\mathrm{i}}\right), 29.13\left(\mathrm{Me}_{t \mathrm{Bu}}\right), 25.06(\mathrm{Me}), 19.65,18.29\left(\mathrm{Me}_{\mathrm{i}}, \mathrm{Me}_{\mathrm{i}^{\prime}}\right)$.

$R_{\mathrm{Ru}}, R_{\mathrm{C}}, R_{\mathrm{S}}$ diastereomer (32 \%). ${ }^{1} \mathrm{H} N \mathrm{NMR}\left(500.13 \mathrm{MHz}, \mathrm{CDCl}_{3}, 223 \mathrm{~K}, \mathrm{ppm}\right): \delta 7.57$ $7.34\left(\mathrm{~m}, 5 \mathrm{H}, \mathrm{H}_{\mathrm{Ar}}\right), 6.02,4.91,4.87,3.26\left(4 \times \mathrm{d}, J=5.2 \mathrm{~Hz}, 4 \mathrm{H}, \mathrm{H}_{\mathrm{A}}, \mathrm{H}_{\mathrm{B}}, \mathrm{H}_{\mathrm{A}^{\prime}}, \mathrm{H}_{\mathrm{B}^{\prime}}\right), 4.80$ (d, $\left.J=4.4 \mathrm{~Hz}, 1 \mathrm{H}, \mathrm{C}^{*} \mathrm{H}\right), 4.00$ (d, $\left.J=5.2 \mathrm{~Hz}, 1 \mathrm{H}, \mathrm{CH}_{2} \mathrm{Ph}\right), 3.64-3.46$ (m, $1 \mathrm{H}, \mathrm{CH}_{2} \mathrm{Ph}$ ), 2.73 (sept, $J=6.7 \mathrm{~Hz}, 1 \mathrm{H}, \mathrm{H}_{\mathrm{i}}$ ), 2.34 - 1.99 (m, 2H, $\mathrm{CH}_{2} \mathrm{C}^{*}$ ), 1.76 (s, 3H, Me), 1.35 (brs, 9H, $\left.\mathrm{Me}_{t \mathrm{Bu}}\right) 0.98\left(\mathrm{~d}, J=6.3 \mathrm{~Hz}, 3 \mathrm{H}, \mathrm{Me}_{\mathrm{i}}\right), 0.89\left(\mathrm{~d}, J=5.5 \mathrm{~Hz}, 3 \mathrm{H}, \mathrm{Me}_{\mathrm{i}^{\prime}}\right) .{ }^{13} C\left\{{ }^{1} H\right\} N M R$ (125.8 MHz, $\left.\mathrm{CDCl}_{3}, 223 \mathrm{~K}, \mathrm{ppm}\right): \delta 180.62(\mathrm{C}=\mathrm{O}), 160.99\left(\mathrm{C}=\mathrm{O}_{\text {Вос }}\right), 134.67,130.31$, 129.28, $129.15\left(\mathrm{C}_{\mathrm{Ar}}\right), 106.06,92.38$ ( $\left.\mathrm{C}_{\text {p-cymene }}\right)$, 86.04, 84.75, 81.10, $77.07\left(\mathrm{CH}_{\mathrm{A}}, \mathrm{CH}_{\mathrm{B}}\right.$, $\left.\mathrm{CH}_{\mathrm{A}^{\prime}}, \mathrm{CH}_{\mathrm{B}^{\prime}}\right), 77.95\left(\mathrm{C}_{t \mathrm{Bu}}\right), 65.41\left(\mathrm{C}^{*}\right), 40.97\left(\mathrm{CH}_{2} \mathrm{Ph}\right), 33.44\left(\mathrm{CH}_{2} \mathrm{C}^{*}\right), 31.06\left(\mathrm{CH}_{\mathrm{i}}\right)$, $28.78\left(\mathrm{Me}_{t \mathrm{Bu}}\right), 24.47(\mathrm{Me}), 20.24,19.12\left(\mathrm{Me}_{\mathrm{i}}, \mathrm{Me}_{\mathrm{i}^{\prime}}\right)$.

\section{Crystal Structure Determination of Complex 6aSb}

X-Ray diffraction data were collected at 100(2) K with graphite-monochromated Mo $\mathrm{K} \alpha$ radiation $(\lambda=0.71073 \AA)$ using narrow $\omega$ rotations $\left(0.3^{\circ}\right)$ on a Bruker SMART APEX diffractometer. Intensities were integrated and corrected for absorption effects with SAINT-PLUS ${ }^{21}$ and SADABS ${ }^{22}$ programs. The structure was solved by direct methods with SHEXLS-2013 ${ }^{23}$ and refined by full-matrix least-squares refinement on $F^{2}$ with SHELXL-2014. ${ }^{24}$ The absolute configuration was determined on the basis of the previously known internal references, and this assignment was confirmed using the Flack parameter. $^{25}$

Crystal data for complex $6 \boldsymbol{a S b}$ : $\mathrm{C}_{20} \mathrm{H}_{27} \mathrm{~F}_{6} \mathrm{IrNO}_{2} \mathrm{SSb} ; M=773.44$; yellow prism, $0.140 \times$ $0.161 \times 0.240 \mathrm{~mm}^{3}$; orthorhombic, $P 2{ }_{1}{ }_{2}{ }_{2}{ }_{1} ; a=8.6130(4) \AA, b=14.4659(6) \AA ⿻, c=$ 19.2824(8) $\AA ; Z=4 ; V=2392.52(18) \AA^{3} ; D_{c}=2.147 \mathrm{~g} / \mathrm{cm}^{3} ; \mu=6.837 \mathrm{~mm}^{-1} ; \mathrm{min}$. and max. absorption correction factors 0.293 and $0.422 ; 2 \theta_{\max }=57.18^{\circ} ; 34612$ collected 
reflections, 5816 unique reflections; $R_{\text {int }}=0.0202$; number of data/restraint/parameters 5816/2/340; final GoF 1.116; $R_{1}=0.0137$ [5764 reflections, $I>2 \sigma(I)$ ]; $w R 2=0.337$ all data; Flack parameter $x=-0.0051(15)$; largest difference peak $0.908 \mathrm{e} \cdot \AA^{-3}$. Hydrogen atoms (except those of methyl groups) have been included in the model in observed positions and freely refined. Two geometrical restraints in a $\mathrm{C}-\mathrm{H}$ and an $\mathrm{N}-\mathrm{H}$ bond lengths have been included in the refinement.

\section{Acknowledgments}

We thank the Ministerio de Economía y Competitividad of Spain (CTQ2012-32095, CTQ2013-40855-R and CTQ2015-67366-P) Gobierno de Aragón and European Social Fund (Grupos Consolidados: Catalizadores Organometálicos Enantioselectivos, Aminoácidos y Péptidos and Inorganic Molecular Architecture) for financial support. M. C. acknowledges Diputación General de Aragón, CSIC and European Social Fund for a grant. R. R. and P. G. O. acknowledge CSIC, European Social Fund and Ministerio de Economía y Competitividad of Spain for a JAE and a Ramón y Cajal (RYC-2013-13800) grants and for a PTA contract, respectively. 


\section{Notes and references}

1 (a) J. Paradowska, M. Stodulski and J. Mlynarski, Angew. Chem. Int. Ed. 2009, 48, 4288-4297. (b) Comprehensive Coordination Chemistry II, J. A. McCleverty and T. J. Meyer, Eds.; Elsevier Science, 2003. (c) J. Chin, S.-S. Lee, K.-J. Lee, S. Park and D. H. Kim, Nature 1999, 401, 254-257. (d) K. Severin, R. Bergs and W. Beck, Angew. Chem. Int. Ed. 1998, 37, 1635-1654. (e) T. G. Appleton, Coord. Chem. Rev. 1997, 166, 313-359. (f) N. Paulic and N. Raos, J. Coord. Chem. 1994, 31, 181-190. (g) A. Iakovidis and N. Hadjiliadis, Coord. Chem. Rev. 1994, 135/136, 17-63. (h) H. Kozlowski and L. D. Pettit, In Chemistry of the Platinum Group Metals; Hartley, F. R., Ed.; Elsevier: New York, 1991; Chapter 15, p 530. (i) S. H. Laurie, In Comprehensive Coordination Chemistry; Wilkinson, G., Ed.; Pergamon: Oxford, 1987; Vol. 2, Chapter 20.2, p 739-776. (j) A. A. Ioganson, Russ. Chem. Rev. 1985, 54, 277-292. (k) L. D. Pettit and M. Bezer, Coord. Chem. Rev. 1985, 61, 97-114.

2 See for example: (a) L. E. H. Paul, B. Therrien and J. Furrer, Inorg. Chem. 2012, 51, 1957-1067. (b) G. W. Karpin, J. S. Merola and J. O. Falkinham, Antimicrob. Agents Chemother. 2013, 57, 3434-3436. (c) L.-C. Königsberger, E. Königsberger, G. Hefter and P. M. May, Dalton Trans. 2015, 44, 20413-20425.

3 Y. Fu, C. Sánchez-Cano, R. Soni, I. Romero-Canelon, J. M. Hearn, Z. Liu, M. Wills and P. J. Sadler, Dalton Trans. 2016, 45, 8367-8378.

4 (a) P. Haquette, M. Salmain, K. Svedlung, A. Martel, B. Rudolf, J. Zakrzewski, S. Cordier, T. Roisnel, C. Fosse, and G. Jaouen, ChemBioChem 2007, 8, 224-231. (b) A. Igashira-Kamiyama and T. Konno, Dalton Trans. 2011, 40, 7249-7263. (c) B. O. Leung, F. Jalilehvand, V. Mah, M. Parvez, and Q. Wu, Inorg. Chem. 2013, 52, 4593-4602. (d) D. S. Warner, C. Limberg, F. J. Oldenburg and B. Braun, 
Dalton Trans. 2015, 44, 18378-18385. (e) D. L. M. Suess, C. C. Pham, I. Bürstel, J. R. Swartz, S. P. Cramer and R. D. Britt, J. Am. Chem. Soc. 2016, 138, 11461149.

5 (a) E. G. Talman, W. Brüning, J. Reedijk, A. L. Spek and N. Veldman, Inorg. Chem. 1997, 36, 854-861. (b) N. A. Kratochwil, Z. Guo, P. del S. Murdoch, J. A. Parkinson, P. J. Bednarski and P. J. Sadler, J. Am. Chem. Soc. 1998, 120, 8253-8254.

6 N. C. Kasuga, R. Yoshitaka, Y. Sakai and K. Nomiya, Inorg. Chem. 2012, 51, 1640-1647.

7 F. Wang, H. Chen, J. A. Parkinson, P. del S. Murdoch and P. J. Sadler, Inorg. Chem. 2002, 41, 4509-4523.

8 (a) J. M. Hearn, I. Romero-Canelón, B. Qamar, Z. Liu, I. Hands-Portman and P. J. Sadler, ACS Chem. Biol. 2013, 8, 1335-1343. (b) A. J. Millett, A. Habtemariam, I. Romero-Canelón, G. J. Clarkson and P. J. Sadler, Organometallics 2015, 34, 2683-2694 and references therein.

9 (a) A. Ashraf, M. Kubanik, F. Aman, H. Holtkamp,T. Söhnel, S. M. F. Jamieson, M. Hanif, W. A. Siddiqui and C. G. Hartinger, Eur. J. Inorg. Chem. 2016, 13761382. (b) (b) J. J. Soldevila-Barreda, I. Romero-Canelon, A. Habtemariam and P. J. Sadler, Nat. Commun. 2015, 6, 6582. (c) J. Patalenszki, L. Biró, A. C. Bényei, T. R. Muchova, J. Kasparkova and P. Buglyó, RSC Adv. 2015, 5, 8094-8107. (d) C. G. Hartinger and P. J. Dyson, Chem. Soc. Rev. 2009, 38, 391-401. (e) M. Böge, C. Fowelin, P. Bednarski and J. Heck, Organometallics 2015, 34, 1507-1521. (f) K. Purkait, S. Chatterjee, S. Karmakar and A. Mukherjee, Dalton Trans. 2016, 45, 8541-8555. 
10 J. W. Kang, K. Moseley and P. M. Maitlis, J. Am. Chem. Soc. 1969, 91, 59705977.

11 M. A. Bennet, T. N. Huang, T. W. Matheson and A. K. Smith, Inorg. Synth. 1982, 21, 75.

12 M. Carmona, R. Rodríguez, F. J. Lahoz, P. García-Orduña, I. Osante, C. Cativiela, J. A. López and D. Carmona, Dalton Trans. 2016, 45, 14203-14215.

13 (a) R. S. Cahn, C. Ingold and V. Prelog, Angew. Chem., Int. Ed. Engl. 1966, 5, 385-415. (b) V. Prelog and G. Helmchen, Angew. Chem., Int. Ed. Engl. 1982, 21, 567-583. (c) C. Lecomte, Y. Dusausoy, J. Protas, J. Tirouflet and A. Dormond, J. Organomet. Chem. 1974, 73, 67-76.

14 D. Cremer and J. A. Pople, J. Am. Chem. Soc. 1975, 97, 1354-1358.

15 S. D. Troup, M. F. Ward, M. Jaspars and W. T. A. Harrison, Acta Crystallogr. 2001, E57, 0535-0537.

16 K. Nakamoto, Infrared and Raman Spectra of Inorganic and Coordination Compounds, 4th ed.; Wiley-Interscience: New York, 1986.

17 Complexes 2a and $\mathbf{2 b}$ crystallize with 1 and 3 water molecules, respectively. Hydrogen bond interactions between the carboxylic $\mathrm{OH}$ group and water molecules account for the chemical shift value measured for the carboxylic proton.

18 D. Carmona, F. J. Lahoz, R. Atencio, L. A. Oro, M. P. Lamata, F. Viguri, E. San José, C. Vega, J. Reyes, F. Joó and A. Kathó, Chem. Eur. J. 1999, 5, 1544-1564.

19 An alternative process consisting of the rotation of the Boc group around the N-C bond has been considered. We have discarded this process because the activation 
parameters, $\Delta \mathrm{S}^{\#}=-3.0 \mathrm{cal} \cdot \mathrm{mol}^{-1} \cdot \mathrm{K}^{-1}$ and $\Delta \mathrm{H}^{\#}=15.6 \mathrm{kcal} \cdot \mathrm{mol}^{-1}$, calculated (B3LYP, 6-31G**/LanL2DZ) are strongly distinct to the experimentally determined by NMR, $\Delta \mathrm{S}^{\#}=-44.3 \pm 6.0 \mathrm{cal} \cdot \mathrm{mol}^{-1} \cdot \mathrm{K}^{-1}$ and $\Delta \mathrm{H}^{\#}=-0.55 \pm 0.03$ $\mathrm{kcal} \cdot \mathrm{mol}^{-1}$.

20 Several compounds crystallize with variable amounts of water which are detected by ${ }^{1} \mathrm{H}$ NMR spectroscopy.

21 SAINT+, version 6.01: Area-Detector Integration Software, Bruker AXS, Madison, WI, 2001.

22 (a) R. H. Blessing, Acta Crystallogr. 1995, A51, 33-38. (b) SADABS, Area Detector Absorption Correction Program, Bruker AXS, Madison, WI, 1996.

23 (a) G. M. Sheldrick, Acta Crystallogr. 1990, A46, 467-473. (b) G. M. Sheldrick, Acta Crystallogr. 2008, A64, 112-122.

24 G. M. Sheldrick, Acta Crystallogr. 2015, C71, 3-8.

25 H. D. Flack, Acta Crystallogr. 1983, A39, 876-881. 


\section{For table of contents use only}

\section{Half-Sandwich Complexes of Iridium and Ruthenium Containing Cysteine-Derived Ligands}

María Carmona, ${ }^{a}$ Ricardo Rodríguez, ${ }^{\text {a, }}$ Fernando J. Lahoz, ${ }^{\text {a }}$ Pilar García-Orduña, ${ }^{a}$ Carlos Cativiela, ${ }^{b}$ José A. López ${ }^{\mathrm{a}}$ and Daniel Carmona, ${ }^{\mathrm{a}, *}$

${ }^{a}$ Instituto de Síntesis Química y Catálisis Homogénea (ISQCH), CSIC - Universidad de Zaragoza, Departamento de Química Inorgánica, Pedro Cerbuna 12, 50009 Zaragoza, Spain, E-mail: dcarmona@unizar.es,riromar@unizar.es

${ }^{b}$ Instituto de Síntesis Química y Catálisis Homogénea (ISQCH), CSIC - Universidad de Zaragoza, Departamento de Química Orgánica, Pedro Cerbuna 12, 50009 Zaragoza, Spain

Modified cysteines display five distinct coordination modes towards $\left(\mathrm{C}_{5} \mathrm{Me}_{5}\right) \mathrm{Ir}$ and $\left(\eta^{6}\right.$ $\left.p-\mathrm{MeC}_{6} \mathrm{H}_{4} \mathrm{iPr}\right) \mathrm{Ru}$ moieties. From spectroscopic and crystallographic data, the absolute configuration of the resulting quiral compounds has been established.

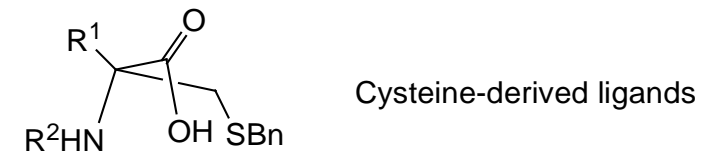<smiles>c1sc2nc1CCN2</smiles><smiles>[M]1CCCOC1</smiles><smiles>[M]1NCCO1</smiles>

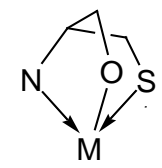<smiles></smiles>

Coordination modes 